\title{
Rusya'da Dijital Hükümet Oluşturulmasında Sivil Katılım Unsuru*
}

\author{
Sevgi KÖK $K^{1} \&$ Maxim LUKYANOV ${ }^{2}$
}

\section{Özet}

Günümüzde dijital hükümetin oluşturulmasını sağlayan en temel sebeplerin başında kamu politikası ve yönetimi reformları gelmektedir. Dünyanın birçok ülkesinde olduğu gibi Rusya'da da planlı ekonominin geliştirilmesi adına dijital hükümete geçiş programları kabul edilmiştir. Devletlerde, dijital hükümet oluşturulması gerekliliği düşüncesinin temelinde yatan sebep, bu yeni teknoloji uygulaması sayesinde bürokrasinin daha az ve daha hızlı hale geleceği, mevcut hizmet sunma yöntemine kıyasla daha az maliyetli olacağı hatta neredeyse insansız kamu hizmeti sunma fırsatı yakalayacakları düşüncesidir. Çalışmanın temel amacı Rusya'daki dijital hükümet alanındaki uygulamaları incelemek ve değerlendirmesini yapmaktır. Makale, dijital hükümet ortamında politika firsatlarına yeni bir bakış açısı fikrini geliştirmeye çalışmaktadır. Ampirik bir temelde, Rus vatandaşlarının dijital hükümetin kullanımına yönelik tutumları Qualitative Comparative Analysis (fs/QCA) yöntemi kullanılarak incelenmiştir. Çalışma sonuçlarının kamu politikası ve kullanılan yöntemi itibariyle dijital bir hükümet kurma ve etkinliğinin izlenebilme pratiği açısından önem taşıdığı düşünülmektedir.

Anahtar Kelimeler: Dijital hükümet, kamu politikası, firsat penceresi, ortak-üretim, Rusya.

\section{Civic Participation in the Formation of Digital Government in Russia}

\begin{abstract}
Today, public policy and management reforms are one of the main reasons for the creation of digital government. In Russia, as in many countries of the world, transition programs to the digital government have been adopted in order to improve the planned economy. In the states, the reason underlying the idea of the creation of digital government is the idea that this new technology will enable the bureaucracy to become less and faster, less expensive than the existing method of service provision, and even offer an almost unmanned public service. The main purpose of the study is to examine and evaluate the applications in the field of digital government in Russia. The paper seeks to develop a new perspective on policy opportunities in the digital government environment. On an empirical basis, Russian citizen's attitudes towards the use of digital government were examined using the Qualitative Comparative Analysis (fs / QCA) method. It is thought that the results of the study are important in terms of the application of a digital government and monitoring of its effectiveness in terms of public policy and the method used.
\end{abstract}

Key words: Digital government, public policy, window of opportunity, co-production, Russia

\footnotetext{
* Bu çalışma Rus Araştırma Vakfı tarafından 18-011-00756 sayılı hibe yardım kararı sonucu "Issledovaniye grazhdanskogo uchastiya v publichnom upravlenii v usloviyakh formirovaniya tsifrovogo pravitelstva” başlı̆̆ı ile Rusya Federasyonu'nda yapılmıştır.

1 Doktora Öğrencisi, St. Petersburg.Devlet Üniverstesi, ORCID: 0000-0001-7209-0461, kok.sevgi@mail.ru

2 Doktora Öğrencisi, St. Petersburg.Devlet Üniverstesi, ORCID: 0000-0002-0166-5501, mledvert@mail.ru
} 


\section{Giriş}

Bu sosyolojik çalışma, Ekim-Kasım 2018 tarihleri arasında St. Petersburg ve Leningrad Bölgesi’nde 3 örneklem büyüklüğü 300 katılımcı ile gerçekleştirilmiştir.

Qualitative Comparative Analysis (fs/QCA) (Niteliksel Karşılaştırmalı Analiz) vaka yapılandırmalarını incelemek için araştırmacılara yeni ve sistematik bir yol sunar. Bu analiz yöntemi karşılaştırmalı ve vaka çalışması araştırmalarında bir yöntem olarak tercih edilmektedir. QCA analistleri verileri niteliksel olarak yorumlarken, değişkenler arasındaki nedenselliğe de bakmaktadır (Rihoux ve Ragin 2009). Araştırma yapılırken seçilmiş olan küçük bir örneklem büyüklüğü, bazı veri işleme araçlarının yalnızca en önemli ve kararlı kalıpları ortaya çıkardığını, ancak istatistiksel olarak önemli özelliklerin tespit edilmesine izin vermediğini ve bizleri bunun yalnızca örneklem büyüklüğüyle bağlantılı olduğu sonucuna ulaştırmıştır. Örneğin, bu durum parametrik olmayan bir ölçütle ilişkili standardize edilmiş kalıntıların analizinde örneklem boyutuna çok hassas olan ki-kare istatistiklerinin hesaplanmasında olduğu gibi bir analitik aracın kullanımı ile ilgilidir. Sonuç olarak, bu çalışmanın her aşamasında, tüm modeller tespit edilememiş ve bu nedenledir ki bu veya benzer diğer olgularda örneklem sayısının eksikliğine bağlı olarak ortaya çıkabilecek sonuçlar metodolojik olarak savunulamaz durumdadır. Diğer bir söylemle, bu rapor yalnızca istihbaratın sağlandığı araştırma aşamasında önemli ve sürdürülebilir olarak karakterize edilebilen kalıpları yansıtacaktır.

Örneklemin kontrol parametreleri, nüfusun; cinsiyet, yaş ve eğitim seviyesi özelliklerine uygun olarak seçilmiştir. Araştırmanın temel hedefi, e-hükümet hizmetlerinin nüfus ve dijital ekonomiye geçiş adımlarının yanı sıra kullanım esnasında kalite memnuniyetini ve talep durumunu incelemekle ilgili bir dizi çalışma hipotezini test etmekti. Araştırmanın görevi ise; bu ilişkilerin sistemdeki en sürdürülebilir kalıpları ve onları tanımlayan faktörleri ortaya çıkarmaya çalışmaktı. Bu mevcut çalışma sonuçlarının 2019'daki araştırma çalışmalarının hedeflerini, yapısını ve yöntemini önceden belirlemeye yardımcı olacağı düşünülmektedir.

\footnotetext{
${ }^{3}$ Rusya Federasyonu'nun Kuzey-Batı Federal Bölgesi'nin 2. Bölgesi, St. Petersburg federal öneme sahip bir şehir olup, Federasyon'un en büyük ikinci şehridir.
} 


\section{Genel Sorular}

Soru 1: «Cinsiyetiniz?»

Tablo:1 Cinsiyet Dağılımı (\%)

\begin{tabular}{|l|c|}
\hline \multicolumn{1}{|c|}{ Cevap seçenekleri } & $\%$ \\
\hline 1. Erkek & 48,0 \\
\hline 2. Kadın & 52,0 \\
\hline Toplam & 100,0 \\
\hline
\end{tabular}

Kota örnekleme parametrelerine uygun olarak, erkeklerin \%48'i ve kadınların \%52'si ile görüşülmüştür.

Soru 2: «Yaşınız?»

Tablo:2 Katılımcıların Yaşı (\%)

\begin{tabular}{|l|c|}
\hline \multicolumn{1}{|c|}{ Cevap seçenekleri } & $\%$ \\
\hline $1.18-29$ yaş & 18,7 \\
\hline 2. 30-39 yaş & 20,7 \\
\hline 3. 40-49 yaş & 15,3 \\
\hline 4. 50-59 yaş & 17,3 \\
\hline 5. 60 yaş ve üstü & 28,0 \\
\hline Toplam & 100,0 \\
\hline
\end{tabular}

Ankete katılanlar arasında katılımcıların yaş durumları; 18-29 \%18,7, 30-39 \%20,7, 40-49 $\% 15,3,50-59 \% 17,3,60 \% 28$ 'dir olarak belirlenmiştir.

Soru 3: «Eğitim durumunuz?»

Tablo:3 Katılımcıların Eğitim Düzeyi (\%)

\begin{tabular}{|l|l|}
\hline \multicolumn{1}{|c|}{ Cevap Seçenekleri } & $\%$ \\
\hline 1. İlkokul mezunu, ortaöğretim terk & 1,3 \\
\hline 2. Ortaöğretim (ortaokul) & 8,0 \\
\hline 3. İlköğretim (lise mezunu) & 3,3 \\
\hline 4. Genel-Mesleki lise & 42,0 \\
\hline 5. Üniversite (henüz okumakta olanlar ve terk etmişler) & 8,0 \\
\hline 6. Yükseköğretim & 37,3 \\
\hline Toplam & 100,0 \\
\hline
\end{tabular}

Yine ankete katılanların arasında \%1,3 ile ilkokul, \%8 ortaöğretim, \%3,3 ilköğretim, \%42,0 mesleki lise veya benzeri okul mezunları, \%8 yükseköğretime devam eden veya terk edenler, \%37,3 ile yükseköğretim mezunları bulunmaktadır. 
Soru 4: «Ailenizde kişi başına aylık ortalama gelir miktarı nedir?»

Tablo:4 Her Aile Üyesi İçin Aylık Gelir Düzeyi (\%)

\begin{tabular}{|l|l|}
\hline \multicolumn{1}{|c|}{ Cevap seçenekleri } & $\%$ \\
\hline 1. 10000 ruble $^{4}$ ve alt1 & 4,7 \\
\hline 2. $10000-15000$ ruble arası & 21,3 \\
\hline 3. 15000-25000 ruble aras1 & 26,0 \\
\hline 4. 25000-40000 ruble aras1 & 28,0 \\
\hline 5. 40000 ruble üstü & 12,0 \\
\hline 6. Fikrim yok & 2,0 \\
\hline 7. Cevap vermeyi reddeden & 6,0 \\
\hline Toplam & 100,0 \\
\hline
\end{tabular}

Aile üyesi başına en fazla 150 Amerikan dolarına varan en düşük gelire sahip katılımcıların payı \%4,7, gelirleri 150-250 dolar arasında değişenler \%21,3, 250-400 dolar arasında olanlar \%26, 400-700 dolar olanlar \%28, 700 dolar üstü \%12 ve fikri olmayanların oranı \%2'dir. Katılımciların $\% 6$ '1 ise her aile üyesi başına aylık gelir düzeyinin sorulduğu bu soruya cevap vermeyi reddetmiştir.

Soru5: «Bütün insanları maddi refahlarına göre birkaç sınıfa böldüğünüzde, kişisel olarak kendinizin hangisine ait olduğunuzu düşünürsünüz?»

Tablo:5 Katılımcıların Statü Öz Değerlendirmesi (\%)

\begin{tabular}{|l|l|}
\hline \multicolumn{1}{|c|}{ Cevap seçenekleri } & $\%$ \\
\hline 1. Yüksek gelir grubu & 0,7 \\
\hline 2. Yüksek ve orta gelir arasında & 8,7 \\
\hline 3. Orta gelir grubu & 41,3 \\
\hline 4. Orta gelir ve alt gelir grubu arasında & 33,3 \\
\hline 5. Alt gelir grubu & 14,0 \\
\hline 6. Fikrim yok & 2,0 \\
\hline Toplam & 100,0 \\
\hline
\end{tabular}

Genel olarak gelir durumuna bakıldığında ankete katılanların \%1'inden azı kendilerini üst gelir grubu sıralamasında, \%8,7'si üst ve orta gelir grubu arasında, \% 41,3'ü orta sınıf, \% 33,3'ü orta ve alt gelir grubu arasında, \%14'lük kısım ise kendilerini alt gelir grubunda görmektedir. Kat1lımcıların \%2'i bir fikri olmadığını belirtmiştir. Sonuca bakıldığında katılımcıların neredeyse \%50'si kendilerini düşük gelir gruplarına dâhil etmiştir.

\footnotetext{
${ }^{4}$ Ekim-Kasım 2018 tarihleri arasında 1 dolar $\approx 65$ rubledir.
} 
Soru 6: «Mesleğiniz nedir?»

Tablo:6 Katılımcıların Mesleği (\%)

\begin{tabular}{|l|c|}
\hline \multicolumn{1}{|c|}{ Cevap seçenekleri } & $\%$ \\
\hline 1. Çalışan (endüstriyel, inşaat, nakliye, tarım v.d.) & 10,0 \\
\hline 2. Mühendis, teknik uzman & 6,7 \\
\hline 3. Yönetim birimi çalışanı & 5,3 \\
\hline 4. Kültür, eğitim, bilim, sağlık çalışanı & 12,7 \\
\hline 5. Ticaret-tüccar sınıfı & 6,7 \\
\hline 6. Girişimci & 9,3 \\
\hline 7. Asker (Ordu, İçişleri Bakanlığı, güvenlik, Rusya Ulusal Muhafızları, & 2,0 \\
\hline vb.) & 9,3 \\
\hline 8. Hizmet sektörü çalışanı (REU, ev hizmeti, ev dışı güvenlik, vb.) & 4,7 \\
\hline 9. Ev hanımı (doğum izni, çocuk bakımı izni, vb) & 10,7 \\
\hline 10. Üniversite öğrencisi ve teknik öğrenci & 20,0 \\
\hline 11. Emekli (çalışmayan) & 0,6 \\
\hline 12. İşsiz & 2,0 \\
\hline 13. Diğerleri & 100,0 \\
\hline Toplam & \\
\hline
\end{tabular}

Ankete katılanlar arasında en önemli grubu \%20 gibi bir oranla emekliler oluşturmuştur. Bunun dışında; \%12,7'sini kültür, eğitim ve bilim adına çalışan kesim, \% 10'u çalışan, \%10 öğrenci, \% 9'unu kamu çalışanı ve diğer gruplar \% 7'den daha az bir kesim olmuştur.

Soru 7: «Yerleşim yeri olarak daimi ikametgah adresiniz neresidir?»

Tablo:7 Katılımcının İkamet Tipi (\%)

\begin{tabular}{|l|c|}
\hline \multicolumn{1}{|c|}{ Cevap seçenekleri } & $\%$ \\
\hline 1. Büyükşehir & 48,0 \\
\hline 2. Bölge olarak ifade edilen yerleşim yerleri & 16,0 \\
\hline 3. Şehir tipi yerleşimler & 16,7 \\
\hline 4. Kasaba ve köy sakinleri & 19,3 \\
\hline Toplam & 100,0 \\
\hline
\end{tabular}

Ankete katılanların arasında \%48'i büyükşehirlerde, \%16'sı bölge olarak ifade edilen yerleşim yerlerinde, \%16,7 şehir tipi yerleşimlerinde ve \%19,3’ü kasaba ve köylerde oturmaktadır. 


\section{E-hükümet Sisteminin Kullanımı}

Soru 8: «Birkaç yıldır ülkede MFTS'ler (mnogofunktsionalnyy tsentr: $М Ф Ц^{5}$ ) faaliyet göstermektedir. Sorunlarınızı çözmek ve ihtiyacını olan belgeleri elde etmek için kişisel olarak çok işlevli merkezlere (MFTS) hiç başvuru yaptınız mı?»

Tablo:8 Katılımcıların MFTS 'ler Ille İletişim Kurma Deneyimi (\%)

\begin{tabular}{|l|c|}
\hline \multicolumn{1}{|c|}{ Cevap seçenekleri } & $\%$ \\
\hline 1. Evet & 80,0 \\
\hline 2. Hayır & 19,3 \\
\hline 3. Fikrim yok & 0,7 \\
\hline Toplam & 100,0 \\
\hline
\end{tabular}

St. Petersburg ve Leningrad Bölgesindeki katılımcıların 4/5'ü çok işlevli merkezlere başvuru konusunda deneyim sahibidir.

Soru 9: « MFTS'ye başvurunuzun sonuçlarından ne derece memnun kaldınız?»

Tablo:9 MFTS'lere Başvuranların Memnuniyet Derecesi (\%)

\begin{tabular}{|l|l|}
\hline \multicolumn{1}{|c|}{ Cevap seçenekleri } & $\%$ \\
\hline 1. Çok memnun & 40,8 \\
\hline 2. Memnun & 30,0 \\
\hline 3. Ne evet ne hayır & 21,7 \\
\hline 4. Memnun değil & 2,5 \\
\hline 5. Kesinlikle memnun değil & 3,3 \\
\hline 6. Fikrim yok & 1,7 \\
\hline Toplam & 100,0 \\
\hline
\end{tabular}

Ankete katılanların \%6'dan azı çok fonksiyonlu hizmet veren bu merkeze başvurmanın sonuçlarından memnun değilken, katılımcıların yaklaşık \%41'inin son derece yüksek oranda memnun (tamamen memnun), \%30'unun memnun, \%21,7'inin ise çelişkili duygular (bazı konularda evet, bazı konularda hayır) kaydettiği görülmüştür. Katılımcılara bir bütün olarak bakıldığında yaklaşık \%71'i olumlu değerlendirmede bulunmuştur.

Kombine tablolarının analizinde MFTS'lere başvurmada deneyim sahibi olanların tecrübeleri göz önünde bulundurulduğunda, çeşitli e-hükümet göstergelerine yönelik tutumların değerlendirilmesi sırasında aşağıdaki unsurlar MFTS'lere itirazın tek başına bir faktör olmadığını gösterdi:

- Rusya Federasyonu'ndaki dijital ekonominin gelişmesine ve elektronik belge dolaşımının genişlemesine kesin olumlu veya olumsuz bir tutum oluşturulması;

\footnotetext{
${ }^{5}$ MFTS (mnogofunktsionalnyy tsentr): Rusya'da bu kuruma başvuranların tek bir talebinin ardından "bir pencere" ilkesiyle devlet ve belediye hizmetleri sunan çok işlevli bir devlet kurumu. Aynı zamanda, devlet hizmetleri sunan kuruluşlarla veya belediye hizmetleri sunan kuruluşlarla etkileşim halinde olup, başvuru sahibinin katılımı olmadan gerçekleşmesi gereken tüm işlevler bu merkez tarafından yürütülmektedir.
} 
- $\quad$ Elektronik dokümanlara güven seviyesi;

- Elektronik belge dolaşımını kullanırken vatandaşların kişisel bilgi güvenliğini değerlendirmesi, elektronik kamu hizmeti sistemi kullanıcılarının kullanımına uygunluk, elektronik belge dolaşımının başlatılmasından sonra devlet yapılarının çalışma hızı, elektronik kamu hizmetleri hakkında bilginin kalitesi;

- Elektronik platformlar ve tercih edilen dosyalama yöntemi kullanılırken kişisel verilerin gizlilik düzeyine ilişkin görüşler.

Ancak tüm bu konularda dâhil olmak üzere, soruların cevaplanmasında MFTS'lere başvuru tecrübesine sahip olmayan insanlar, herhangi bir hizmetten yararlanan insanlara göre cevap verme konusunda daha çok zorlanmaktadırlar.

Ankete katılan tüm katılımcılardan sırasıyla \%32,7 "oldukça memnun" ve \%24,1 "memnun" olmak üzere olumlu değerlendirmelerde bulundular. MFTS'lere bakıldığında ise; olumlu görüşlerin oranı \%71'dir. Bu durumu MFTS'nin iş kalitesinin yüksek olduğu şeklinde değerlendirmek mümkündür.

\section{Kamu Hizmetleri İnternet Ana Kapısının ${ }^{6}$ Kullanımı}

Soru 10: «Ülkede birkaç yıldır kamu ve belediye hizmetleri tek bir bilişim kapısı üzerinden faaliyet göstermektedir (Gocuslugi $\left.{ }^{7}\right)$. Resmi verilere göre Rusya nüfusunun \%40'ından fazlası bu bilişim kapısına kayıtlıdır. Kamu ve belediye hizmetlerinin tek bir bilişim kapısı üzerinden faaliyet gösterdiği bu hizmetten daha önce yararlandınız mı?»

Tablo:10 Kamu Hizmetleri Bilişim Kapısını Kullanma Deneyimi (\%)

\begin{tabular}{|l|l|}
\hline \multicolumn{1}{|c|}{ Cevap seçenekleri } & \multicolumn{1}{c|}{$\%$} \\
\hline 1. Evet & 50,7 \\
\hline 2. Hayır & 47,3 \\
\hline 3. Fikrim yok & 2,0 \\
\hline Toplam & 100,0 \\
\hline
\end{tabular}

St. Petersburg ve Leningrad Bölgesinde, hükümet hizmetleri bilişim kapısına erişim seviyesi, ülkedeki ortalama göstergelere karşıl1k gelmekte olup \%50,7'dir.

Soru 11: «Sizce kamu ve belediye hizmetlerinin tek bir bilişim kapısı üzerinden faaliyet gösterdiği bu sistemden hangi hizmetlerin elde edilebileceğini düşünüyorsunuz (Gosuslugi)?

\footnotetext{
6 "Bilişism kapısı" portal kelimesi yerine kullanılmıştır. Bkz. TDK.

${ }^{7}$ Госуслуги (Gosuslugi): Rusya'da kamu hizmetleri için elektronik bilişim kapısıdır. https://www.gosuslugi.ru/ (Elektronnyy portal polucheniya gosudarstvennykh uslug).
} 
$\mathrm{Bu}$ soru katılımcılara herhangi bir kamu hizmetleri bilişim kapısı işlevlerinin listesi açıkça gösterilmeden sorulmuştur. Katılımcıların cevapları kesinlikle bilişim kapısının en sık kullanılan hizmetlerine karşıllı gelmektedir.

Soru 12: «Hangi hizmetler sizin için önemlidir? Gerekli tüm seçenekleri işaretleyiniz.»

Tablo:12 Hükümet hizmetleri Bilişim Kapısındaki Hizmet Önem Siralamasının Değerlendirilmesi (\%)

\begin{tabular}{|l|l|}
\hline \multicolumn{1}{|c|}{ Cevap seçenekleri } & $\%$ \\
\hline Hastane randevusu & 63,3 \\
\hline Yurtışı için pasaport ${ }^{8}$ başvurusu & 54,7 \\
\hline Fatura ödemeleri & 50,7 \\
\hline Vergi borç kontrolü & 46,0 \\
\hline Vergi ödemesi & 44,0 \\
\hline Rusya içi pasaport başvurusu & 42,7 \\
\hline Emeklilik fonuna başvurma & 36,7 \\
\hline Vergi kimlik numarası başvurusu & 36,0 \\
\hline İkamet ya da konaklama yeri için kayıt yaptırma & 32,7 \\
\hline Araç kaydı & 32,0 \\
\hline İs arama ve istihdam & 29,3 \\
\hline Sabıka kaydı sorgulaması & 27,3 \\
\hline Araçların devlet teknik muayenesi & 26,0 \\
\hline Yardımların ve ödemelerin kaydı & 26,0 \\
\hline Karayolu trafik alanında idari suçlar hakkında SMS ile yazılı bilgi edinebilme & 25,3 \\
\hline Rusya Yol Güvenliği Devlet Müfettişliği kaydı & 25,3 \\
\hline Anaokuluna çocuk kayıt işlemleri ve okul sırasını kontrol etme & 24,7 \\
\hline Devlet sosyal yardımının sağlanması, sosyal hizmetler hakkında bilgi & 24,0 \\
\hline Vatandaş belgelerinde veri değişikliği işlemleri & 22,7 \\
\hline Sürücü yeterlilik sınavlarına başvuru ve ehliyet alımı & 20,7 \\
\hline İş hukuku danışmanlığı & 20,0 \\
\hline Doğum kaydı & 17,3 \\
\hline Tüzel kişiliklerin ve girişimcilerin tescili & 16,0 \\
\hline Bir kişinin hukuksal borcu hakkında bilgi & 14,7 \\
\hline Sigortalı kişilerin zorunlu emeklilik sigortası sisteminde bireysel hesaplarının durumuu & 14,0 \\
\hline hakkında bilgi & \\
\hline Evlilik başvurusu & 14,0 \\
\hline Doğum yardımı sorgulaması & 12,0 \\
\hline Dava sorgulama & \\
\hline Av izni belgesi ve düzenlemeler & 10,0 \\
\hline
\end{tabular}

${ }^{8}$ Rusya Federasyonu vatandaşlarının kullanmış oldukları yurtiçi (kimlik belgesi fakat pasaport düzeninde) ve yurtdışı olmak üzere iki çeşit pasaport vardır. 


\begin{tabular}{|l|l|}
\hline Malların sertifikalandırılması konusunda bilgi sunulması & 4,7 \\
\hline Reklam yasalarının ihlali konusunda şikâyet başvurusu & 4,7 \\
\hline Diğerleri & 4,0 \\
\hline
\end{tabular}

Kamu hizmetleri bilişism kapısının en popüler cevapları (cevap verenlerin yarısından fazlası için geçerli): \%63,3 ile hastane randevusu almak, \%54,7 ile pasaport başvurusu ve \%50,7 oranında fatura ödemesi olmuştur.

Hükümet hizmetleri bilişim kapısı tarafından sunulan av izni belgesi ve düzenlemeler $\% 10,7$, malların sertifikalandırılması konusunda bilgi sunulması \%4,7, reklam mevzuatı ihlallerine ilişkin şikâyetlerin bildirilmesi $\% 4,7$ ve diğer hizmetlere rağbet $\% 4$ bandında gözlenerek en az talep edilen hizmetler olarak ortaya çıkmıştır.

Ek olarak, bilişim kapısı tarafından sağlanan farklı sayıda elektronik kamu hizmetini kullanmaya hazır olan grupların boyutuna dair de bir analiz yapılımıștır.

Tablo:13 Elektronik Hizmetlerin Potansiyel Talep Miktarı (\%)

\begin{tabular}{|l|l|}
\hline \multicolumn{1}{|c|}{ Kamu hizmetlerinin sayıs1 } & \multicolumn{1}{c|}{$\%$} \\
\hline 0-5 arası hizmet sayıs1 & 40,0 \\
\hline 6-10 aras1 hizmet sayıs1 & 32,0 \\
\hline 11-15 arası hizmet sayıs1 & 13,3 \\
\hline 16-20 arası hizmet sayıs1 & 7,3 \\
\hline 21-25 arası hizmet sayıs1 & 4,7 \\
\hline 26-31 aras1 hizmet sayıs1 & 2,7 \\
\hline Toplam & 100,0 \\
\hline
\end{tabular}

Şimdiye kadar katılımcıların \%40'1 0 ila 5 arası hizmetten, \% 32'si 6 ila 10 arasında değişen hizmetten, \% 13,3'ü 11-15 arasında değişen hizmetten, \% 7,3'ü 16'dan 20'ye kadar olan hizmetlerden, $\%$ 4,7'si 21-25 arasında değişen hizmetten, \% 2,7'si ise 26 hizmet ve daha fazlası konusunda talepte bulunmuştur.

Belirli sayıda kamu hizmetinin kendileri için önemini değerlendiren katılımcıların sosyodemografik profil analizi aşağıdaki gibidir:

Kamu hizmetleri bilişim kapısının 0'dan 5'e kadar olan hizmetleri, 60 yaşından büyük katılımcılar, emekliler, küçük bir şehrin sakinleri veya şehir tipi yerleşimlerde yaşayan gruplar tarafindan önemli olarak kabul etmektedir.

Kamu hizmetleri bilişim kapısının 6 ila 10 arasında değişen hizmetlerinin önemli olduğu düşünenler; daha çok eksik eğitim gören kişiler, mühendis ve teknik işlerde uğraşan katılımcılar ile ev hanımları (doğum sonrası bakım izninde olan kadınlar dâhil) olmuştur.

Kamu hizmetleri bilişim kapısının 11'den 15'e kadar olan hizmetlerini en çok; 40 ila 49 yaşları arasında, yükseköğrenim gören, bilim, kültür ve eğitim alanlarındaki işçilerin yanı sıra, çalışma 
gruplarında kendilerini “diğer" olarak sınıflandıran ve büyükşehirlerde yaşayan insanların kullandığı gözlemlenmiştir.

Kamu hizmetleri bilişim kapısının 16-20 arasında değişen hizmetleri daha çok yaşları 50 ila 59 arasındaki katılımcılar ve işçi ve yönetici kategorisinde bulunan katılımcılar tarafından kullanılmaktadır.

Kamu hizmetleri bilişim kapısında vatandaşlar için verilen 21'den 25'e kadar olan hizmetleri büyük ölçüde 50 ila 59 yaş arasındaki katılımcılar ile ortaöğretim ve mesleki eğitim alan kişiler tarafindan işaretlenmiştir.

Kamu hizmetleri bilişim kapısının 26 ya da daha fazla işlevinden faydalanan ve diğer gruplara bakarak kendileri için bu hizmetlerin daha önemli olduğunu düşünen kişiler ise daha çok mesleki eğitim almış, üniversite öğrencileri ile aylık geliri 40.000 rublenin üzerinde insanlar olmuştur. 
Tablo:14 Kamu Hizmetleri İnternet Ana Kapısının Farklı Sayıdaki İslevlerini Kendileri İçin Önemli Olarak Değerlendiren Grupların Büyüklüğ̈̈ (\%)

\begin{tabular}{|c|c|c|}
\hline Kullanılan kamu hizmeti sayısı & $\%$ & Birikmiş \% \\
\hline 1,00 & 9,3 & 9,3 \\
\hline 2,00 & 5,3 & 14,7 \\
\hline 3,00 & 8,0 & 22,7 \\
\hline 4,00 & $\mathbf{9 , 3}$ & 32,0 \\
\hline 5,00 & 8,0 & 40,0 \\
\hline 6,00 & 10,0 & 50,0 \\
\hline 7,00 & 10,7 & 60,7 \\
\hline 8,00 & 2,7 & 63,3 \\
\hline 9,00 & 4,7 & 68,0 \\
\hline 10,00 & 4,0 & 72,0 \\
\hline 11,00 & 8,0 & 80,0 \\
\hline 12,00 & 0,7 & 80,7 \\
\hline 13,00 & 1,3 & 82,0 \\
\hline 14,00 & 0,7 & 82,7 \\
\hline 15,00 & 2,7 & 85,3 \\
\hline 16,00 & 2,7 & 88,0 \\
\hline 17,00 & 1,3 & 89,3 \\
\hline 18,00 & 2,0 & 91,3 \\
\hline 19,00 & 0,7 & 92,0 \\
\hline 20,00 & 0,7 & 92,7 \\
\hline 21,00 & 1,3 & 94,0 \\
\hline 22,00 & 1,3 & 95,3 \\
\hline 23,00 & 1,3 & 96,7 \\
\hline 24,00 & 0,7 & 97,3 \\
\hline 26,00 & 0,7 & 98,0 \\
\hline 30,00 & 0,7 & 98,7 \\
\hline 31,00 & 1,3 & 100,0 \\
\hline Toplam & 100,0 & \\
\hline
\end{tabular}

Kümülatif / birikmiş yüzde verilerine göre; katılımcıların 1/3'i burada bulunan hizmetlerden en fazla 4'ünü, katılımcıların yarısı en fazla 6'sın1, nüfusun 2/3'den fazlası ise yine hizmet bilişim kapısı tarafından sağlanan 30 hizmetten en fazla 6'sını kullanmaktadır.

Gosuslug bilişim kapısının kullanım seviyeleri dikkate alındığında karşımıza üç önemli nokta çıkmaktadır:

İlk olarak; şu anda nüfus tarafından kullanılan çeşitli hizmetlerin dağılımında dengesizlik; 
İkinci olarak; bilişim kapısının vatandaşları yönlendirme stratejisinin çeşitli sosyal gruplar üzerindeki etkisizliği;

Üçüncü olarak; nüfusun elektronik hükümet hakkında bilgi politikasının iyileştirilmesi için çalışma güncellenmesi yapılmasının gerekliliğidir.

Çalışma süresince, kamu hizmetleri bilişim kapısında elektronik hizmet kullanma deneyiminin aşağıdakilerle ilgili olduğu bulunmuştur:

- Elektronik belge dolaşımının genişlemesine ilişkin olumlu bir tutum (bağlantı doğrudan, istatistiksel olarak anlamlıdır, Pearson korelasyon katsayısı +0.408 'dir);

- $\quad$ Elektronik kamu hizmetleri sistemi ve belge akışı kullanıcıları için uygunluğun olumlu bir değerlendirmesi (bağlantı doğrudan, istatistiksel olarak önemlidir, Pearson korelasyon katsayısı +0.46 'd1r);

- Çalışanlarla iletişim kurmadan belgeleri elektronik olarak göndermenin çok daha uygun olduğu fikridir (bağlantı doğrudan, istatistiksel olarak önemlidir, Pearson korelasyon katsayısı +0.507 'dir).

Hükümet hizmetleri bilişim kapısına erişme konusunda deneyime sahip olan kişilerin, elektronik belge yönetimine güvenmeleri ve elektronik belge yönetiminin başlatılmasından sonra devlet kuruluşlarında çalışmaların hızlandığı pozitif olarak değerlendirdiği gözlemlenmiştir. Aynı zamanda dijital platformlanı kullanırken kişisel verilerin gizliliğinin garanti altına alındığı konusunda güvenleri vardır (ilgili tablo hücrelerinde pozitif istatistiksel olarak standartlaştırılmış dengeler ile belirtilmektedir).

Hükümet hizmetleri bilişim kapısı tarafından sunulan hizmetlerinden hangilerinin katılımcılar için önemli hizmetler içerisine girdiğinin açıklığa kavuşturulması anlamında çok boyutlu bir ölçeklendirme yöntemi uygulandı. Grafiğin sağ tarafında çok boyutlu ölçeklendirmenin sonuçları ile kamu hizmetleri bilişim kapısının en sık kullanılan işlevleri, solda ise en az kullanılanları yer almaktadır.

Analiz, en sık paylaşılan e-hükümet hizmetlerinin birkaç gruba ayrılmasını mümkün kılmıştır (bu kullanan katılımcı sayısını azaltmak amacıyla düzenlenmiştir).

1. Grup - ev ve aile konularında sorunları çözmek, hastaneden randevu almak, faturaları ödemek gibi konulardaki hizmetleri bir araya getirir.

2. Grup - devletin yapmakla yükümlü olduğu, örneğin; vergi ve borçları kontrol etmek, vergileri ödemek, yurtiçi ve yurtdışı pasaport başvurusu yapmak, kimlik numarası almak gibi hizmetleri birleştirir. 
3. Grup - araç tescili için trafiğe başvurma, ehliyet başvurusu yapmak, araçların teknik muayenesi, karayolu trafiği alanındaki idari ihlaller hakkında bilgi, alınan para cezalarına ilişkin SMS bildirimi almak, ikametgâh veya konaklama için kayıt yaptırmak, vatandaş belgelerindeki verilerin değiştirilmesi, yardım alınması, tüzel ve bireysel girişimcilerin kayıt başvurusu, adli sicil kaydı gibi konulardaki hizmetleri birleştirir.

4. Grup - sosyal problemleri çözme konularında, örneğin; okul yaşı gelmiş çocuğun okula kayıt ettirilmesi, sırasının takibinin yapılması, emeklilik fonuna başvurmak, devlet sosyal yardımına başvuru yapmak, sosyal hizmetler, iş hukuku konusunda danışmanlık, iş arama ve istihdam hakkında bilgi gibi hizmetleri birleştirir.

5. Grup - belirli sosyal grupları (eşler, genç ebeveynler, girişimciler, çıkar grupları) etkileyen aşağıdaki işlevleri içerir: evlilik kaydı için başvuruda bulunmak, çocuk doğduğunda nüfusa kayıt başvurusu yapmak, doğum yardımına başvuru yapmak, sigortalı kişilerin bireysel durumları hakkında bilgi edinebilmesi, zorunlu emeklilik sigortası sistemindeki kişisel hesap durumunun kontrolü, av izni almak, malların sertifikalandırılması hakkında bilgi verilmesi, reklamcılıkla ilgili mevzuatın ihlal edilmesi ve diğer bazı konulardaki hizmetleri birleştirir. Sistem tarafından verilen hizmetler arasında bulunan emeklilik fonuna yapılan itiraz ise oldukça nadirdir.

Katılımcılar bilişim kapısı e-hizmetlerinin sayısının (potansiyel olarak önemli en az 16 hizmet türü) kendileri için önemli olduğunu belirtmiş, böylece analiz, vatandaşların kendilerine verilen elektronik kamu hizmetlerinin kesinlikle uygun olduğunu düşünmeye meyilli olduklarını göstermiştir.

Gosuslug bilişim kapısı üzerindeki elektronik hizmetlerin sayısı ne kadar az olursa, katılımcı, hizmetleri kendisi için daha önemli görmekte fakat elektronik belge dolaşımının genişlemesi gerekliliğine dair de kayıtsız kalmaktadır.

Katılımcılar arasında diğer gruplara bakarak en fazla kamuda çalışan kişiler elektronik belgelerin yürürlüğe girmesinden sonra devlet kurumlarının çalışma hızındaki artışı fark etmiş ve bilişim kapısı tarafından sağlanan 6-10 arasındaki işlevi daha önemli bulmuşlardır.

Rusya'da aynı zamanda hizmet bilişim kapısı tarafından sunulan hizmetlere yönelik potansiyel taleplerde yüksek göstergelere sahip kişilerin (21'den 25'e kadar önemli hizmetler), devletlerin özel hayatları üzerindeki genel kontrol riskleri ve genel olarak olumsuz tutumları konusunda endişeleri daha belirgindir.

\section{Diğer E-hükümet İnternet Ana Kapılarına Başvuru Durumu}

Soru 13: «Kamu ve belediye hizmetlerini tek bir bilişim kapısı üzerinden veren sistemin hangi hizmetlerde ne ölçüde yararlı firsatlar sunduğu hakkinda sizinle konuştuk. Ancak, Rusya Federasyonu "Bilgi Toplumu” (2011-2020) programı çerçevesinde gelişen diğer e-hükümet hizmetleri de mevcut. 
Şimdi aşağıda isimleri verilecektir. Lütfen okuyup, hangilerini bilip, hangilerini bilmediğinizi söyleyiniz.

Tablo:15 Katılımclların Kaти Hizmeti Internet Ana Kapısına Ek Olarak, E-hükümet Yapılarına Benzer Diğer Hizmetleri Kullanım Durumu (Satır Başına \%)

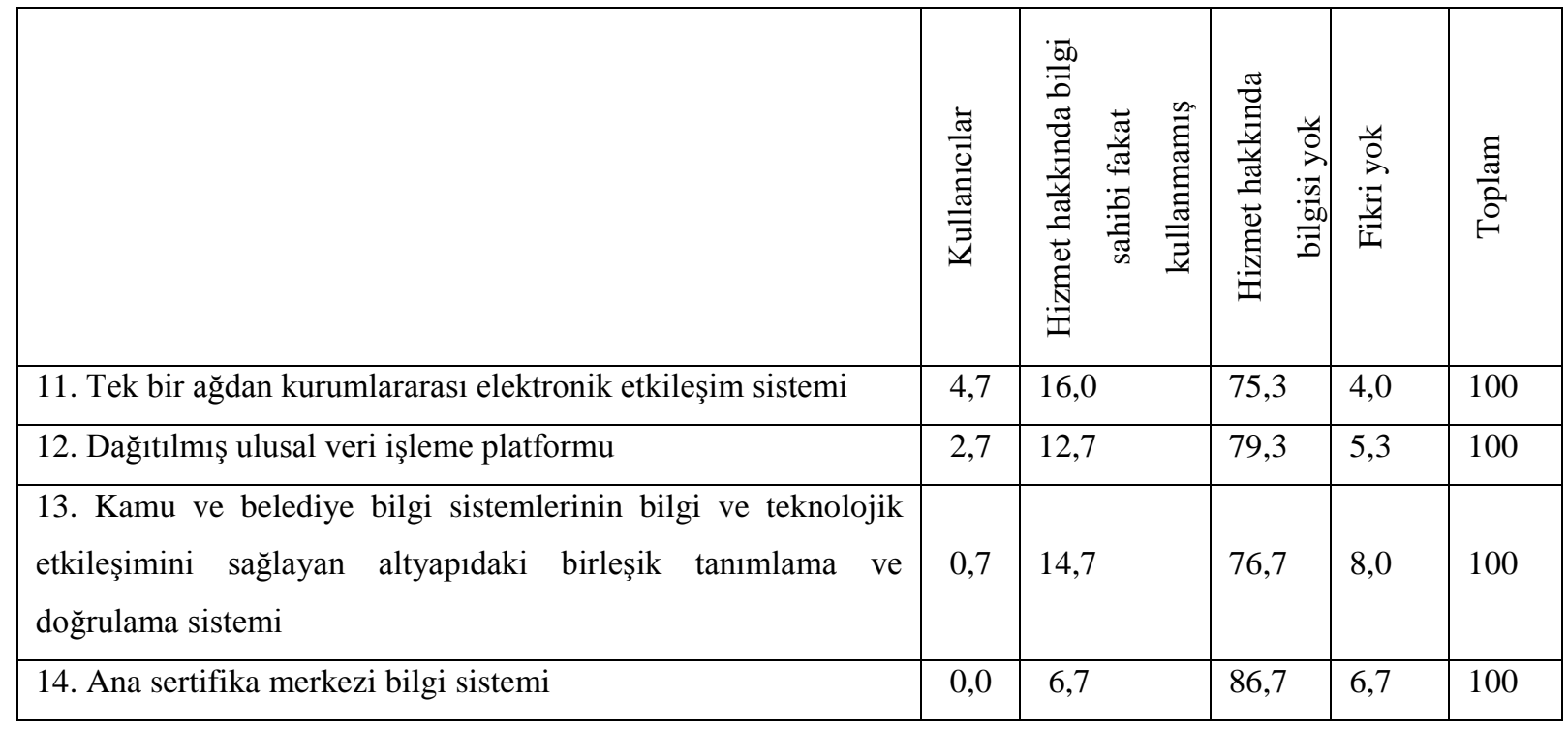

Analiz, geri kalan 4 hizmetin e-hükümet platformu üzerinde neredeyse tüm nüfusa hizmet vermediğini ve bu platformların şu anda çok az talep gördüğünü göstermiştir. Katılımcıların sadece \% 4,7'si bu hizmetleri kullandığını söyledi. Nüfusun 3/4'den 9/10'a kadarı ise konu hakkında bilgi sahibi değildi.

Soru 14: «Şu anki e-hükümet sisteminin kullanım pratiği sizce uygun mudur?»

Tablo:16 Elektronik Kamu Hizmetleri Sistemi Kullanım Pratiğinin Değerlendirilmesi (\%)

\begin{tabular}{|l|c|}
\hline \multicolumn{1}{|c|}{ Cevap seçenekleri } & $\%$ \\
\hline 1. Kesinle uygun & 26,0 \\
\hline 2. Kismen uygun & 52,7 \\
\hline 3. Kesinlikle uygun değil & 6,7 \\
\hline 4. Fikrim yok & 14,7 \\
\hline Toplam & 100,0 \\
\hline
\end{tabular}

Kuşkusuz, katılımcıların sadece dörtte biri (\%26) e-hükümet platformu kullanmanın kolay olduğunu düşünmektedir. Katılımcıların yarısından biraz fazlası (\%52,7) kısmen uygun bulurken, yaklaşık \%7'si kesinlikle uygun olmadığını ve \%14,7'si ise bir fikirlerinin olmadığını belirtmişlerdir. Katılımcıların çeşitli platformlardaki farkındalık düzeyleri ve bu uygulamaları kullanım deneyimleri göz önüne alındığında, bu sorunun katılımcılar için kamu hizmetleri bilişim kapısı kullanım kolaylığının beklentileri ne düzeyde karşıladığı sorusuna net bir cevap olduğu açıktır. 


\section{Elektronik İmza Kullanım Durumu}

Soru 15: «Elektronik imza hakkında bilginiz var? Bugüne kadar hiç kullandınız mı?»

Tablo:17 Elektronik Imza Kullanım Deneyimi (\%)

\begin{tabular}{|l|c|}
\hline \multicolumn{1}{|c|}{ Cevap seçenekleri } & $\%$ \\
\hline 1. Biliyorum ve kullanıyorum & 22,0 \\
\hline 2. Biliyorum fakat kullanmıyorum & 48,0 \\
\hline 3. Ne biliyorum ne de kullanıyorum & 28,7 \\
\hline 4. Fikrim yok & 1,3 \\
\hline Toplam & 100,0 \\
\hline
\end{tabular}

Katılımcıların \%22'si elektronik imza kullandıklarını beyan etmiştir. Ankete katılanların neredeyse yarıs (\%48) elektronik imzayı duymuştur, ancak kullanma tecrübesi yoktur. Katılımcıların yaklaşık \%29'unun ise elektronik imza hakkında hiçbir fikri yoktur.

Bununla birlikte, kombine tabloların analizi, elektronik imza kullanma tecrübesine sahip kişilerin, elektronik iş akışının (Pearson korelasyon katsayısı +0.371) uygulamalarına tam olarak güvenme eğilimini göstermiştir. Yani elektronik iş akışının genişlemesi tam olarak desteklenmiş, devlet tarafindan verilen bu hizmetin uygulanması konusunda endişe etmek için bir neden olmadığı kabul edilmiştir.

\section{E-Hükümet Formları Kullanımının Çok Değişkenliği}

İtirazın çokluk faktörünün önemini açıklığa kavuşturmak ve e-hükümet kullanmaya yönelik tutumlar oluşturmak için çeşitli platformlara ve araçlara açıklık getirmek amacıyla ek hesaplamalar yapılmıştır.

Tüm bu 5 platformun yanı sıra çok fonksiyonlu hizmet veren sistemin ve e-imzanın herhangi bir yanıtlayıcıyı kullanmadığı tespit edildi. Kullanılan platformların ve araçların maksimum sayısı 4 'tür.

Tablo:18 E-hükümet Platformlarının ve Araçlarının Kullanımının Çok Değişkenliği (\%)

\begin{tabular}{|l|l|}
\hline \multicolumn{1}{|c|}{ Platform ve araç sayıs1 } & \multicolumn{1}{c|}{$\%$} \\
\hline 0 & 15,3 \\
\hline 1 & 25,3 \\
\hline 2 & 36,7 \\
\hline 3 & 19,3 \\
\hline 4 & 3,3 \\
\hline Toplam & 100,0 \\
\hline
\end{tabular}

Katılımcıların \%15,3'ü herhangi bir araç ve / veya platform kullanmıyor, \%25,3'ü bir kullanıyor, \% 36,7'si iki kullanıyor (hükümet hizmetleri bilişim kapıs1), \%19,3'ü üç ve \%3,3'ü dört adet kullanmaktadir. 
Farklı bir sayıda e-hükümet aracı ve platformu kullanan grupların sosyo-demografik profilinin aşağıdaki özellikleri belirlenmiştir.

Diğer katılımcılardan farklı olarak, 60 yaşın altındaki katılımcılar, emekliler, ayda aile üyesi başına 250 doların altında gelire sahip bireyler e-hükümet hizmetleri kullanma konusunda hiçbir tecrübeye sahip değildir.

Bir e-hükümet aracı / platformu diğer gruplardan daha büyük ölçüde çalışmayan emekliler tarafından ve hizmet çalışanları tarafından kullanılma eğilimindedir.

İki e-hükümet aracı / platformunu, öğrencilerle birlikte 30-39 yaş aralığındaki katılımcıların kullanması diğer gruplara göre daha fazladır.

Üç e-hükümet aracı / platformu, 40 ila 49 yaşları arasındaki katılımcılar, yükseköğrenim mezunları, orta gelir seviyesine sahipler ve her aile üyesi için aylık 40.000 rublenin üzerinde gelir sahipleri tarafından kullanılma eğilimindedir.

Dört e-hükümet aracı / platformu, geliri her bir aile üyesi için aylık 40.000 rublenin üstünde olan, kendilerini üst ve orta gelir durumu arasında tanımlayan insanlar tarafından daha çok kullanılma eğilimindedir.

Farklı platformların ve e-hükümet araçlarının kullanımı, elektronik kamu hizmetleri sistemi kullanıcıları için kolaylık değerlendirmesiyle ilişkili olduğu ortaya çıkmıştır. Kullanılan platform sayısı ne kadar fazlaysa, negatif değerlendirmeler o kadar az eğilimlidir (Pearson korelasyon katsayısı $-0.411)$.

Kullanılan platform sayısı ile e-hükümet araçları arasındaki ilişki şu şekilde teyit edilmiştir:

- $\quad$ Elektronik kamu hizmetleri sistemi kullanıcıları için uygunluğun değerlendirilmesi (Pearson korelasyon katsayısı 0,411'e eşittir);

- $\quad$ Elektronik belge dolaşımının genişlemesiyle ilişki (Pearson korelasyon katsayısı 0,48 'e eşittir);

- $\quad$ Elektronik belge dolaşımına güven (Pearson korelasyon katsayısı 0.414'e eşittir);

- $\quad$ Elektronik belge dolaşımının başlamasından sonra ofis yapılarının devlet yapılarındaki hızının tahmini (Pearson korelasyon katsayısı 0.433'e eşittir);

- Katılımcılar tarafindan farklı araçlar ve platformları kullanma deneyimi ne kadar az olursa (Pearson korelasyon katsayısı 0.425 'e eşittir), katılımcılar eski geleneksel belge sunma yöntemine daha fazla özlem duymaktadır.

Dijital ekonomi ve nüfusu elektronik hizmet türleri hakkında bilgilendirme yeterliliğinin değerlendirilmesinde, istatistiksel olarak anlamlı korelasyon katsayıları bulunamamıştır. Ancak 
istatistiksel olarak anlamlı standartlaştırılmış kalıntılar düzeyinde, cevap verenler tarafından kullanılan e-hükümet araçlarının sayısı arttıkça, cevap verenlerin kullandıkları oranın ne kadar olumlu olduğu doğrulanmıştır. Dijital ekonomiye geçişte yeterli bilgi sağlandığı düşünüldüğünde bu durum özellikle en az 4 platform / araç kullanan insanlar için geçerlidir.

Çok boyutlu ölçeklendirme ve korelasyon analizi, e-hükümete yönelik tutum değerlendirmesinin çeşitli göstergeleri açısından en önemli olanın, MFTS ile iletişim kurma ve hükümet hizmetleri bilişim kapısı kullanma deneyimi olduğunu göstermiştir (yanıt verenlerin\% 47,3'ü birlikte kullanılmıştır).

Bu iki yapıya başvurmanın en önemli faktörleri vatandaşların yaşıdır; insanlar ne kadar yaşlı olursa, uygulamaları kullanım düzeyi o kadar az olur (Pearson korelasyon katsayısı -0.384'tür). Emekliler, aylık gelir durumu 250 dolara kadar olan insanlar uygulamada daha az tecrübeye sahiptir. İstatistiksel olarak anlamlı standartlaştırılmış kalıntıların değerlendirilmesi göstermiştir ki; bu hizmet en çok, aylık gelir durumu 400 doların üzerinde olan insan grubuna hitap etmektir.

E-hükümet göstergelerinin değerlendirilmesinde olduğu gibi platformları ve araçları kullanım deneyimleri olan kişilerin, MFTS'ye ve Gasuslug bilişim kapılarına erişim konusunda deneyimleri değerlendirilirken, aşağıdaki istatistiksel olarak anlamlı korelasyon katsayıları ortaya çıkmıştır:

- $\quad$ Elektronik kamu hizmetleri sistemi kullanıcıları için uygunluğun değerlendirilmesi (Pearson korelasyon katsayısı, 0.395'e eşittir);

- $\quad$ Elektronik belge dolaşımının genişlemesiyle ilişki (Pearson korelasyon katsayısı $0,392)$

- $\quad$ Elektronik belge dolaşımına güven (Pearson korelasyon katsayısı 0.374'e eşittir);

- $\quad$ Elektronik belge dolaşımının başlamasından sonra devlet yapılarındaki hizmet hızı (Pearson korelasyon katsayısı 0.395 'e eşittir);

- Katılımcılar tarafindan farklı araç ve platformları kullanma deneyimi ne kadar az olursa (Pearson korelasyon katsayısı - 0,501); katılımcılar eski geleneksel belge sunma yöntemi için daha fazla özlem duymaktadır.

Ek olarak analiz, kamu hizmetleri bilişim kapısı ile MFTS'nin eşzamanlı olarak kullanılması kullanıcıların zihninde aşağıdaki durumlar ile ilişkili sorunlar olduğunu göstermiştir:

- $\quad$ Elektronik platformlar kullanılırken kişisel verilerin gizliliğinin garantisi;

- $\quad$ Elektronik belge yöntemi kullanırken vatandaşların kişisel bilgi güvenliği;

- Elektronik hükümet hizmetleri hakkında vatandaşları bilgilendirmenin faydası; 
- Rusya Federasyonu'nda dijital ekonomi geliştirme ihtiyacı (istatistiksel olarak anlamlı standartlaştırılmış kalıntılar düzeyinde ilgili gruplar için onaylandı).

\section{Elektronik Belge Formlarına Karşı Tutum}

Soru 16: «E-hükümet sayesinde artık bir vatandaş ihtiyaç duyduğu belgelere teknik cihazlarla (kağıtsız/bürokrasi olmadan) etkileşime girerek ulaşabilmektedir. Siz kişisel olarak belgeleri doldurmak ve kamuya açık hizmetleri elektronik bir bilişim kapısından almayı mı ya da daha önce olduğu gibi, idari bir binaya giderek belgeleri belirli bir çalışandan teslim almayı mı daha uygun buluyorsunuz?»

Tablo:19 Ankete Katılanların Elektronik Bir Biçimde ya da Bir Kamu Görevlisine Belgeleri Sunma Önceliği (\%)

\begin{tabular}{|l|l|}
\hline \multicolumn{1}{|c|}{ Cevap seçenekleri } & $\%$ \\
\hline 1. Çalışan ile iletişim kurmadan, elektronik olarak almak daha uygun & 54,0 \\
\hline 2. Belgeleri önceden olduğu gibi bir görevliden teslim etmek daha uygundur & 41,3 \\
\hline 3. Fikrim yok & 4,7 \\
\hline Toplam & 100,0 \\
\hline
\end{tabular}

Mevcut durumda hala vatandaşların algılarında elektronik veya bir kamu görevlisinden belge temin etme tercihlerine ilişkin bir bölünme vardır. Yarıdan fazlası (\%54) elektronik yolun bir kamu görevlisi ile iletişime geçmek zorunda olmaktan daha iyi olduğuna inanırken, \%41,3'ü belge, beyanname vb. işlemleri çalışanlar ile iletişim kurarak yapmayı tercih etmektedir. Katılımcıların \%5'i ise fikri olmadığını beyan etmiştir.

Soru 17: «Artık elektronik belge dolaşımının kullanımının genişletilmesi, örneğin; elektronik imza kullanımı, elektronik arşiv kullanımı, iş ilişkilerinin elektronik kaydına geçişi gibi hizmetlerden bahsediliyor. Siz bu durum hakkında ne düşünüyorsunuz?»

Tablo:20 Ankete Katılanların Elektronik Belge Listesindeki Hizmetlerin Genişletilmesine Karşı

Tutuти $(\%)$

\begin{tabular}{|l|l|}
\hline \multicolumn{1}{|c|}{ Cevap seçenekleri } & \multicolumn{1}{c|}{$\%$} \\
\hline 1. Kesinlikle destekliyorum & 23,3 \\
\hline 2. Destekliyorum & 36,7 \\
\hline 3. Desteklemiyorum & 14,7 \\
\hline 4. Kesinlikle desteklemiyorum & 5,3 \\
\hline 5. Benim için bu konu önemli değil & 15,3 \\
\hline 6. Fikrim yok & 4,7 \\
\hline Toplam & 100,0 \\
\hline
\end{tabular}

Cevaplara bakıldığında, katılımcıların \%20'si ülkedeki elektronik servislerin sayısının artması gerekliliği konusunda gelişmiş bir görüşe sahip değil. Her beş kişiden birisi de bu süreci olumsuz 
değerlendirmektedir (\%5,3'ü desteklememektedir ve \%14,7'si hiç desteklememektedir). Ankete katılanların 3/5'i ise elektronik belge sayısının geniş̧letilmesine ilişkin olumlu görüşlerini dile getirmiştir (\% 23,3'ü tam destek, \% 36,7'si destek vermiştir).

Soru 18: "Ülkede kâğıt evrak formlarından elektronik evrak dolaşımına geçmek için çalışmalar söz konusu. Şu andaki elektronik belge yönetimi türlerine ne ölçüde güveniyorsunuz?»

Tablo:20 Katılımcıların Mevcut Elektronik Belge Dolaşım Biçimlerine Olan Güvenleri (\%)

\begin{tabular}{|l|l|}
\hline \multicolumn{1}{|c|}{ Cevap seçenekleri } & $\%$ \\
\hline 1. Kesinlikle güveniyorum & 11,3 \\
\hline 2. Güveniyorum & 27,3 \\
\hline 3. Bazı konularda evet, bazı konularda hayır & 34,7 \\
\hline 4. Güvenmiyorum & 14,7 \\
\hline 5. Kesinlikle güvenmiyorum & 7,3 \\
\hline 6. Fikrim yok & 4,7 \\
\hline Toplam & 100,0 \\
\hline
\end{tabular}

Ankete katılanların yaklaşık \%40'ı şu anda mevcut olan elektronik belge dolaşım biçimlerine güven duyuyor (\%11,3'ü tamamen güveniyor, \% 27,3'ü güveniyor). Üçte birinden fazlası tartışmalı bir değerlendirme yaparak, bazı konularda güvendiklerini, bazı konularda ise güven duymadıklarını $(\% 34,7)$ belirtmiştir. Katılımcıların \%20'den fazlası mevcut elektronik belge yönetimi türlerine güvenmiyor (\%14,7'si güvenmiyorken, \%7,3 kesinlikle güvenmiyor). Yaklaşık \% 5'i oranında kişi de fikri olmadığını belirtmiştir.

Soru 18: "Elektronik belgelere güven eksikliğinin temel nedenleri nelerdir?"

Devlet elektronik platformlarındaki verilerle ilgili riskler katılımcılar tarafından en s1k cevaplardan en aza doğru aynen onların ağızlarından şu şekilde değerlendirilmiştir:

a) Bilgisayar korsanlığı (hacker) nedeniyle kişisel verilerin sızdırılması (veri güvenliği sorunu, sızıntı korkusu, veriler internet platformunda olduğunda sisteme saldırıldığında kişinin tüm kişisel verilerinin bilgisayar korsanlarının eline geçmesinden, kişisel bilgilerin çalınması, elektronik belgelerin çalınması, verilerin kaybolma ihtimali, başka kişiler tarafından hukuki amaçlarla kişisel verilerin kullanılması, dolandırıcılığa açık olabileceği, birilerinin gizlice/yasadışı olarak tüm bilgilerin öğrenilebilirliği, yetersiz veri koruması, veri kaybı olasılığı, gelişmemiş siber güvenlik, dış müdahalelere karşı yapılandırılmamış koruma, korsanlık, korsanlar tarafından e-postaların çalınması, güvensizlik, kişisel veri sızıntısı, verilerin üçüncü kişilerin eline geçmesinden korkma);

b) Teknik arızalardan kaynaklanan veri kaybı (virüs her şeyi yok eder, bilgisayar arızası, bilgi aktarımı sürecinde olası arızalar, program donuyor, veri yanlış giriliyor, elektronik arıza, kullanıcı faktörü, teknik destek yetersizliği, donanım güvenilir değil); 
c) Belirli insan kategorileri için internet ve elektronik belge formlarını kullanmanın teknik zorlukları (programın yönlendirmesi kullanmak için yetersiz, zor vb., program henüz yeni, kötü çalışıyor, elektronik belge sağlayan bu teknolojiyi tam olarak anlayamıyorum, sistemin nasıl çalıştığını ögrenememek, bu hizmetleri almak için gerekli aygıtları nasıl kullanacağımı bilmiyorum, rahat hissetmiyorum, çok fazla parola, anahtar vb. kullanmanın gerekliliği ve sonrasında bunları hatırlama sorunu yaşıyorum);

d) Genel olarak, elektronik formlara güvensizlik, belgelerin kağıt biçiminde tercih edilmesi (belgelere güvenmiyorum ve ihtiyacım olan bazı hizmetlerin henüz olmaması, eski formların daha kullanımıma uygun olması, elektronik belge dolaşımına pek aşina değilim, internet kullanmaktan hoşlanmıyorum, korkuyorum, ihtiyacım olduğu an sorunumu çözmek ve teknik destek amacıyla sistemde görünür sorumlu kişinin yokluğu);

e) Amaçlı insan aldatmacası (aldatılmaktan korkmak - özellikle yaşlı insanlar, birçok dolandırıcılık yöntemi olduğundan kendimi toplumda genel olarak rahat hissetmiyorum, son dönemlerde yaşanan dolandırıcılık olaylarının artması nedeniyle paranoyak oldum);

f) Kişinin devlet tarafindan sürekli kontrol halinde tutulacağı düşüncesi (bu devletin vatandaştan gizli bilgileri toplamak için çıkardığı bir plandır, böylece vatandaşları daha fazla kontrol edecekler, gözetim konusu).

Soru 19: «Sizce, vatandaşların çeşitli devlet kurumlarındaki sorunlarını elektronik belge ile yayınlanmasından sonra dikkate alınma ve çözümlenme hızı nasıl değişti?»

Tablo:21 Elektronik Doküman Yönetiminin Başlatılmasından Sonraki Sorunların Dikkate Alınma Hızındaki Değişimin Değerlendirilmesi (\%)

\begin{tabular}{|l|l|}
\hline \multicolumn{1}{|c|}{ Cevap seçenekleri } & \multicolumn{1}{|c|}{$\%$} \\
\hline 1. Davaların dikkate alınma hızı arttı & 50,7 \\
\hline 2. İnceleme oranı değişmedi & 26,7 \\
\hline 3. Vaka yönetimi öncekinden daha yavaş & 3,3 \\
\hline 4. Fikrim yok & 19,3 \\
\hline Toplam & 100,0 \\
\hline
\end{tabular}

Ankete katılanların yarısı elektronik belge yönetiminin yürürlüğe girmesinden sonra sorunlarının dikkate alınma oranının arttığına (\%50,7), 1/4'ü hiçbir şeyin değişmediğine, \%3'ünden fazlası aksine her şeyin yavaşladığına inanmaktadır. Neredeyse 1/5'i (\%19,3) bu konuda herhangi bir fikre sahip değildir. 


\section{Vatandaşların Bilgi Güvenliği Hakkındaki Düşünceleri}

Soru 20: «Kamu ve belediye hizmetlerinin tek bir bilişim kapısı üzerinden verildiği elektronik platformları kullanırken, devletin vatandaşlara kişisel bilgilerinin gizliliğini garanti ettiğini düşünüyor musunuz?»

Tablo:22 Katılımcıların Elektronik Platformları Kullanırken Kişisel Bilgilerin Gizliliğinin Korunmasına İlişkin Görüşleri (\%)

\begin{tabular}{|l|c|}
\hline \multicolumn{1}{|c|}{ Cevap seçenekleri } & $\%$ \\
\hline 1. Evet & 50,7 \\
\hline 2. Hayırr & 28,7 \\
\hline 3. Fikrim yok & 20,7 \\
\hline Toplam & 100,0 \\
\hline
\end{tabular}

Ankete katılanların yarısı $(\% 50,7)$ elektronik platform kullanımının, kişisel bilgilerin gizliliğini ihlal etmediğine (ihlal riski yoktur) inanmaktadır. \% 28,7'si gizlilik kurallarının yerine getirilmediğini düşünürken, \%20,7'si bu soruya cevap verememiştir.

Soru 21: «Elektronik belge yönetiminin vatandaşların kişsisel bilgi güvenliğini gerektiği gibi sağladı̆̆ını düşünüyor musunuz?»

Tablo:23 Vatandaşların Kişisel Bilgi Güvenliğini Sağlama Konusundaki Algıları (\%)

\begin{tabular}{|l|c|}
\hline \multicolumn{1}{|c|}{ Cevap seçenekleri } & $\%$ \\
\hline 1. Evet & 30,0 \\
\hline 2. Hayır & 51,3 \\
\hline 3. Fikrim yok & 18,7 \\
\hline Toplam & 100,0 \\
\hline
\end{tabular}

Ankete katılanların \%30'u elektronik belge yönetiminin vatandaşlara bilgi güvencesi garantisi verdiğini, \%51,3'ünün bunu reddettiğini, \%18,7'si ise cevap vermenin zor olduğunu belirtti.

Soru 22: «Bazı insanlar elektronik belgelerin uygulama kapsamını genişlettikten sonra vatandaşların mahremiyet hakkını kaybedeceğini ve devlet tarafindan tam kontrol altına olacağını savunuyorlar. Bir kısmı ise bunun böyle olmadı̆̆ konusunda ikna olmuş durumda. Siz, kişisel olarak herhangi olumsuz bir durumun olabilme ihtimali konusunda ne düşünüyorsunuz? Yoksa endişe için herhangi bir sebep yok mudur?» 
Tablo:24 Katılımcıların Elektronik Belge Kullanma Konusunda Öznel Algısı (\%)

\begin{tabular}{|l|l|}
\hline \multicolumn{1}{|c|}{ Cevap seçenekleri } & $\%$ \\
\hline 1. Kesinlikle, her zaman risk vardır & 42,0 \\
\hline 2. Risk olabilir & 38,7 \\
\hline 3. Risk için herhangi bir neden yoktur & 11,3 \\
\hline 4. Kesinlikle risk yoktur & 3,3 \\
\hline 5. Fikrim yok & 4,7 \\
\hline Toplam & 100,0 \\
\hline
\end{tabular}

Vatandaşların, devletin mahremiyet haklarını gerçekten ihlal edilebileceğinden ve tamamen kontrol altına alınma riskleri konusundaki kaygı düzeyi çok yüksek olup, katılımcıların 4/5'i (\%42'si bu riskin koşulsuz olduğuna inanmaktadır, \%38,7 risk olma ihtimalinin oldukça makul) bu yönde olumsuz bir cevap vermiştir. Kuşkusuz, ankete katılanların \%3,3'ü korku duyma gerekçesi olmadığına ikna olmuş, \%11,3'ü risk için bir olasılık olmadığına inanmaktadır. Katılımcıların \%4,7'si bir fikirleri olmadıkları gerekçesiyle bu soruya cevap vermemiştir.

Soru 23: «Devlet organlarının elektronik ortamda sundukları hizmetler hakkında vatandaşları yeterince bilgilendirdiğini düşünüyor musunuz?»

Tablo:25 Elektronik Hizmetlerle İlgili Devletten Alınan Bilgilerin Eksiksiz Olduğuna Dair Öznel Değerlendirme (\%)

\begin{tabular}{|l|l|}
\hline \multicolumn{1}{|c|}{ Cevap seçenekleri } & \multicolumn{1}{|c|}{$\%$} \\
\hline 1. Evet & 23,3 \\
\hline 2. Hayır & 64,7 \\
\hline 3. Fikrim yok & 12,0 \\
\hline Toplam & 100,0 \\
\hline
\end{tabular}

Nüfusun dörtte birinden fazlası e-hizmetler ile ilgili bilgi politikasından faydalanıldığın $(\% 23,3)$ haberdar edildiğini, katılımcıların neredeyse 2/3'ü $(\% 64,7)$ ise yeterli bilgilendirildiklerini reddetmektedir. \%12'si ise bir fikri olmadığını beyan etmiştir.

\section{Rusya Federasyonu Ekonomisinin Dijitalleştirilmesi Hakkında Genel Değerlendirme}

Soru 24: «Rusya Federasyonu dijital ekonomisinin ve diğer çeşitli alanlardaki gelişim (ulaşım altyapısının iyileştirilmesi, enerji santrallerinin modernizasyonu, uzay araştırmaları vb.) durumu hakkında iktidar seçkinlerinin sunduğu ve uyguladığı projelere karşı tutumunuz nedir?» 
Tablo:26 Rusya'da Ekonominin Dijitalleşme Oranı İle İlişkisi (\%)

\begin{tabular}{|l|l|}
\hline \multicolumn{1}{|c|}{ Cevap seçenekleri } & $\%$ \\
\hline 1. Genel olarak olumlu & 45,3 \\
\hline 2. Bazı projeler ve yenilikler için olumlu, bazıları için olumsuz & 40,7 \\
\hline 3. Genel olarak olumsuz & 3,3 \\
\hline 4. Diğer & 2,0 \\
\hline 5. Fikrim yok & 8,7 \\
\hline Toplam & 100,0 \\
\hline
\end{tabular}

Ankete katılanlar ekonominin bir bütün olarak dijitalleşmesine yönelik tutumu hakkındaki soruya cevap verirken, \%45,3'ü olumlu olarak değerlendirmiş, \%40,7'si iki yönlü bir tutum olduğunu, $\% 3,3$ olumsuz olduğunu ifade etmiştir. Yanıt verenlerin yaklaşık \%9'u ise cevap vermekte zorlanmıştır.

\subsection{Internete girmek için tercih edilen araçlar}

Soru 25: «Internete erişmek için hangi cihazları kullanıyorsunuz?»

Tablo:27 Internete Erişmek İ̧̧in Kullanılan Araç (\%)

\begin{tabular}{|l|l|}
\hline \multicolumn{1}{|c|}{ Cevap seçenekleri } & $\%$ \\
\hline Akıllı telefonlar & 69,3 \\
\hline Dizüstü bilgisayar & 47,3 \\
\hline Masaüstü bilgisayar & 33,3 \\
\hline Tablet & 25,3 \\
\hline Diğer & 0,7 \\
\hline Hiçbirisini kullanmiyorum & 10,0 \\
\hline Fikrim yok & 0,7 \\
\hline
\end{tabular}

Her on katılımcıdan birisi interneti hiç kullanmadığını belirtti. Dünya çapındaki ağlara erişmek için katılımcıların 2/3'ten fazlası akı1lı telefon kullanıyor (\%69,3), neredeyse yarısı $(\% 47,3)$ bir dizüstü bilgisayar kullanıyor, üçte biri $(\% 33,3)$ bir masaüstü bilgisayar kullanıyor, her dörtte biri $(\% 25,3)$ ise tableti tercih etmektedir.

Ek olarak, katılımcıların paylaştığı ağların, kanalların ve anlık mesajlaşma programlarının sayısı say1d1. 
Tablo:28 Yanıtlayanların Kullandiğı A $\breve{g}$, Kanal ve Haberci Sayısı (\%)

\begin{tabular}{|l|l|}
\hline 0 & 4,0 \\
\hline 1 & 20,0 \\
\hline 2 & 13,3 \\
\hline 3 & 17,3 \\
\hline 4 & 16,7 \\
\hline 5 & 13,3 \\
\hline 6 & 8,0 \\
\hline 7 & 5,3 \\
\hline 8 & 2,0 \\
\hline Toplam & 100,0 \\
\hline
\end{tabular}

Ankete katılanların sadece \%4'ü hiçbirini kullanmıyor, \%20'si bir, \%13,3’ü iki, \%17,3’ü üç, \%16,7'si dört, \%13,3'ü beş, \%8'i altı, \%5,3'ü yedi, \%2’i ise sekiz farklı yöntem kullanmaktadır.

Tablo:29 A ğ ve Anlık Mesajlaşma Programlarını Kullanan Etkinlik Grupları (\%)

\begin{tabular}{|l|l|l|}
\hline Yüksek kaynak çeşitliliği göstergesi & 7 ila 9 ağ ve anlık mesajlaşma programı & 7,3 \\
\hline Kaynak çeşitliliği ortalama göstergesi & 4 ila 6 ağ ve anlık mesajlaşma programı & 38,0 \\
\hline Düşük kaynak çeşitliliği & 1 ila 3 ağ ve anlık mesajlaşma programı & 50,7 \\
\hline Şebekeler ve haberciler kaynakları kullanılmaz & 4,0 \\
\hline Toplam & 100,0 \\
\hline
\end{tabular}

Verileri yeniden gruplandırırken, kullanılan kanalların ve ağların çeşitliliğine göre dört grup birbirinden ayrıldı. Ankete katılanların yarısı 1 ila 3 farklı ağ kaynağı kullanıyor \%50,7 (düşük), 4 ila 6 ağ ve anlık mesajlaşma programı \%38 (ortalama), 7 ila 9 ağ ve anlık mesajlaşma programı \%7,3 (yüksek) ve \% 4 oranında katılımcı herhangi bir ağı kullanmadığını belirtmiştir.

Maksimum kanal çeşitliliği, esas olarak 30 yaşın altındaki genç katılımcılarda, yöneticilerde ve üniversite öğrencilerinde gözlenmektedir. Aynı zamanda bu insanlar elektronik belge dolaşımının genişlemesi konusunda da olumlu bir tutuma sahiptir.

Orta derecede çeşitli kanallar temel olarak 30 ila 60 yaşları arasındaki vatandaşlar, ortaöğretim mezunları, işadamları, askeri personel ve aile üyesi başına ayda 150 dolara kadar gelir elde eden en yoksul insanlar, küçük şehir sakinleri ve şehir tipi yerleşimlerde oturanlar tarafından kullanılmaktadır. $\mathrm{Bu}$ insanlar, elektronik belge dolaşımının genişlemesi konusunda olumlu bir tutuma sahip olup, aynı zamanda elektronik belge dolaşımının başlamasından sonra sorunların çözülme hızının arttığına dair olumlu görüş bildiren gruba kişilerdir.

Son derece sınırlı çeşitlilikte kanallar, çoğunlukla 60 yaşın üzerindeki insanlar, ilkokul mezunları, işçiler, çalışmayan emekliler, her aile üyesi için aylık 200 ila 250 dolar arasında olan gelir sahipleri tarafindan kullanılmaktadır. Bu insanlar elektronik belge yönetiminin genişlemesini destekleme eğiliminde değildir. Elektronik belge akışının başlamasından sonra sorunların dikkate 
alınma hızındaki değişimin tahmin edilmesini zor buluyor ve belgeleri daha öncesinde olduğu gibi belirli bir kamu görevlisinden almanın daha uygun olduğunu düşünüyorlar.

Genellikle herhangi bir ağı kullanmama eğilimi, çalışmayan emekli, aile üyesi başına ayda 150 dolara kadar geliri olan, ekonomik olarak yardıma en muhtaç insanlar arasında görülmektedir. $\mathrm{Bu}$ insanlar, elektronik belge dolaşımının genişlemesine karşı diğer gruplardan daha fazla kayıtsız kalmışlardır.

Soru 26: "Internete erişmek için hangi cihazlardan kişisel olarak yararlanmanız daha uygun?»

Tablo:30 Internet Erişimi İçin Cihazların Önceliği (\%)

\begin{tabular}{|l|c|}
\hline \multicolumn{1}{|c|}{ Cevap seçenekleri } & $\%$ \\
\hline Akıllı telefon & 33,3 \\
\hline Masaüstü bilgisayar & 26,7 \\
\hline Dizüstü bilgisayar & 24,0 \\
\hline Tablet & 6,0 \\
\hline Diğer & 1,3 \\
\hline Hiçbirisi & 8,7 \\
\hline Toplam & 100,0 \\
\hline
\end{tabular}

İnternete ulaşmanın en uygun yolu olarak akıllı telefon her üç kişiden birisi $(\% 33,3)$, bir masaüstü bilgisayar ve bir dizüstü bilgisayar her dörtte bir (sırasıyla \%26,7 ve \%24), bir tablet sadece $\% 6$ katılımcı tarafindan belirlendi. 


\subsection{Sosyal ağların ve internet bağlantı kanallarının kullanılmast}

Soru 27: «Hangi sosyal ăg ve hizmetleri kullanıyorsunuz?»

Tablo:31 Katılımcıların Sosyal A ğ ve Hizmetlerden Faydalanma Durumu (\%)

\begin{tabular}{|l|c|}
\hline \multicolumn{1}{|c|}{ Cevap seçenekleri } & $\%$ \\
\hline Vkontakte & 62,0 \\
\hline WhatsApp & 58,7 \\
\hline YouTube & 36,0 \\
\hline Odnoklassniki & 30,7 \\
\hline Instagram & 30,7 \\
\hline Skype & 29,3 \\
\hline Viber & 24,7 \\
\hline Telegram & 20,7 \\
\hline Facebook & 10,0 \\
\hline Twitter & 8,0 \\
\hline My World & 4,7 \\
\hline Linkedln & 1,3 \\
\hline Flickr & 0,7 \\
\hline Tumblr & 0,7 \\
\hline Diğer & 14,0 \\
\hline
\end{tabular}

En çok talep edilenler Vkontakte $(\% 62,05)$ ve WhatsApp’tır $(\% 58,7)$. Katılımcıların yaklaşık üçte biri YouTube (\%36), Odnoklassniki $(\% 30,7)$, Instagram $(\% 30,7)$ ve Skype $(\% 29,3)$ kullanmaktadır. Her dört kişiden birisi Viber $(\% 24,7)$, her beşte biri $(\% 20,7)$ Telegram kullanıyor, her on kişiden birisi (\%10) Facebook, her on üçüncüde (\%8) Twitter kullanmaktadır. Ankete katılanların \% 5'inden azı My World'ü tercih etmektedir.

Çok boyutlu ölçeklemenin sonuçları, en sık paylaşılan ağların, kanalların ve anlık mesajlaşma programlarının aşağıdaki beş farklı kombinasyonunu ortaya çıkarmıştır:

1. Grup şunları içerir: Vkontakte ve WhatsApp.

2. Grup; özellikle görsel bileşenin önemli olduğu kanalları içerir: Instagram ve YouTube.

3. Grup; Odnoklassniki, Skype, Viber.

4. Grupta sadece bir mesajlaşma programı Telegram mevcuttur.

5. Grup daha az kullanılan ağları, kanalları ve anlık mesajlaşma programlarını birbirine bağladı: Facebook ve Twitter, ayrıca My World, Flickr, Linkedln ve Tumblr. 
Hedef grupların bilincini artırmak için e-hükümet ve dijital ekonomi hakkında bilgi yayılırken bu gruplar dikkate alınmalıdır.

Soru 28: «Hangi sosyal ağlara ve hizmetlere güveniyorsunuz?»

Tablo:32 Katılımcıların Sosyal Ağlara ve Hizmetlere Duyduğu Güven (\%)

\begin{tabular}{|l|l|}
\hline \multicolumn{1}{|r|}{ Cevap seçenekleri } & $\%$ \\
\hline WhatsApp & 33,3 \\
\hline Вконтакте & 27,3 \\
\hline Другоe & 24,0 \\
\hline Telegram & 18,7 \\
\hline Skype & 14,7 \\
\hline Odnoklassniki & 13,3 \\
\hline Instagram & 12,0 \\
\hline Viber & 10,0 \\
\hline YouTube & 8,0 \\
\hline Facebook & 4,0 \\
\hline My World & 2,0 \\
\hline Twitter & 1,3 \\
\hline Flickr & 0,0 \\
\hline Linkedln & 0,0 \\
\hline Tumblr & 0,0 \\
\hline
\end{tabular}

Analiz, ankete katılanların diğer siteler ve kanallar hakkında en az üçte birinin Vkontakte ve WhatsApp'a güvendiğini, neredeyse her dördüncünde Telegram'a, yaklaşık \%14'ünün Skype ve Odnoklassniki, her dokuz kişiden birisinin Instagram'a, her on kişiden birisinin Viber'e, her on ikinci kişinin YouTube'a ayrıca Facebook, My World ve Twitter'a ise çok az sayıda katılımcının güven duyduğunu ortaya çıkarmıştır.

Çok boyutlu ölçeklendirmenin analizi, yanıt verenlerin hangi kanallara, ağlara ve haber sitelerine aynı anda güvenme eğiliminde olduklarını da göstermiştir.

1. Güven grubu: Vkontakte ve WhatsApp.

2. Güven grubu: Skype, Viber, YouTube.

3. Grup: Odnoklassniki, Instagram.

4. Güven grubunda Telegram

5. Güven grubu şunları içerir: My World, Facebook, Flickr, Linkedln, Tumblr, Twitter.

6. Güven grubunda ayrıca yalnızca bir cevap vardır - diğer ağlar, kanallar ve anlık mesajlaşma programlar1. 
Rus kullanıcılara 4. ve 6. gruplardaki kaynağa erişimi engellemek için 2018 baharında aktif denemeler yapıldıktan sonra, Telegram katılımcılarının görüşlerinde özel bir durum meydana gelmiş ve engellemede geri adım atılmıştır. Yukarıda sayılan internet kaynakları katılımcıların kişisel ilgi alanlarına uygun olarak düzenlenmiştir (güvenilirliğini artırmak için bir bilgilendirme kampanyası planlanırken bu durum dikkate alınmalıdır).

\begin{tabular}{|l|l|l|l|}
\hline \multicolumn{1}{|c|}{$\begin{array}{c}\text { Cevap } \\
\text { seçenekleri }\end{array}$} & \multicolumn{1}{|c|}{ \% Kullanıcılar } & Güven & Kanal üzerinde bilgi tanıtım etkinliği endeksi \\
\hline Diğer & 14,0 & 24,0 & 1,71 \\
\hline Telegram & 20,7 & 18,7 & 0,90 \\
\hline Facebook & 10,0 & 4,0 & 0,57 \\
\hline WhatsApp & 58,7 & 33,3 & 0,57 \\
\hline Skype & 29,3 & 14,7 & 0,50 \\
\hline Bконтакте & 62,0 & 27,3 & 0,44 \\
\hline My World & 4,7 & 2,0 & 0,43 \\
\hline Odnoklasniki & 30,7 & 13,3 & 0,43 \\
\hline Instagram & 30,7 & 12,0 & 0,41 \\
\hline Viber & 24,7 & 10,0 & 0,40 \\
\hline YouTube & 36,0 & 8,0 & 0,22 \\
\hline Twitter & 8,0 & 1,3 & 0,16 \\
\hline Linkedln & 1,3 & 0,0 & 0 \\
\hline Tumblr & 0,7 & 0,0 & 0 \\
\hline Flickr & 0,7 & 0,0 & 0 \\
\hline
\end{tabular}

Güven seviyesi bakımından en etkili olanlar Telegram, WhatsApp, Skype ve Facebook'tur. Katılımcıların yarısından fazlası (\%50) bu ağlara güven duymaktadır.

Katılımciların \%40 ila \%44'ü, Vkontakte My world, Classmates, Instagram ve Viber gibi ağlara güveniyorken, YouTube (\%22) ve Twitter’a (\%16) güven düzeyi çok düşük çıkmıştır.

\section{1. İnfomatların kullanımı ${ }^{9}$}

Soru 29: «Son yıllarda, bilgi ve iletişim terminalleri (infomat) ortaya çıkmıştır. Hiç kullandınız mi?»

Tablo:33 Infomat Kullanan Kattlımcıların Deneyimi (\%)

\begin{tabular}{|l|l|}
\hline \multicolumn{1}{|c|}{ Cevap seçenekleri } & $\%$ \\
\hline 1. Evet & 9,3 \\
\hline 2. Hayır & 86,0 \\
\hline 3. Fikrim yok & 4,7 \\
\hline Toplam & 100,0 \\
\hline
\end{tabular}

\footnotetext{
${ }^{9}$ Infomat, çeşitli ödeme sistemlerinin ödeme cihazlarına benzeyen bir elektronik terminal cihazıdır.
} 
Cevap verenlerin sadece her on birinci kişiden birisi $(\% 9,3)$ kamu hizmetleri bilişim kapısıyla iletişim kurmak için infomat kullanma tecrübesine sahiptir.

\section{2. İktidar Kurumlarına Karşı Tutum}

Soru 30: «Aşağıdaki kurum ve kuruluşlara ne ölçüde güveniyorsunuz?»

Tablo:34 Iktidar Kurumlarına Karşı Güven (Kurum Başına \%)

\begin{tabular}{|c|c|c|c|c|c|c|c|c|}
\hline Kurumlar & 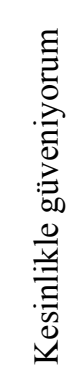 & 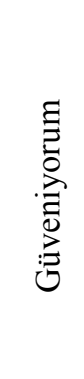 & 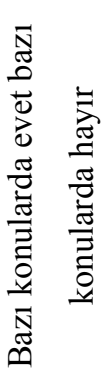 & 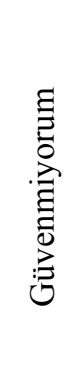 & 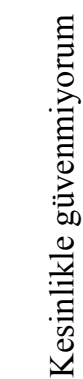 & 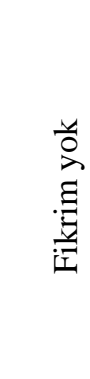 & 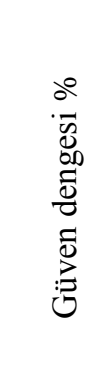 & $\begin{array}{l}\overline{\vec{n}} \\
\frac{\sqrt{0}}{0} \\
\overline{0} \\
0 \\
0 \\
0 \\
: \\
0 \\
0\end{array}$ \\
\hline Yerel İdare, Belediye Meclisi & 5,3 & 19,3 & 32,0 & 17,3 & 17,3 & 8,7 & $-10,0$ & $-0,16$ \\
\hline Bölgesel Yasama Meclisi & 4,7 & 18,7 & 32,7 & 16,0 & 18,0 & 10,0 & $-10,6$ & $-0,18$ \\
\hline Vali & 8,7 & 14,7 & 23,3 & 17,3 & 22,7 & 13,3 & $-16,6$ & $-0,26$ \\
\hline Devlet Dumas1 & 6,7 & 12,0 & 19,3 & 24,0 & 32,0 & 6,0 & $-37,3$ & $-0,50$ \\
\hline Federasyon Konseyi & 6,7 & 14,0 & 21,3 & 20,7 & 28,7 & 8,7 & $-28,7$ & $-0,41$ \\
\hline Rusya Federasyonu Hükümeti & 8,0 & 13,3 & 23,3 & 22,0 & 28,7 & 4,7 & $-29,4$ & $-0,41$ \\
\hline Başbakan D. A. Medvedev & 8,7 & 9,3 & 18,0 & 18,7 & 41,3 & 4,0 & $-42,0$ & $-0,54$ \\
\hline $\begin{array}{llll}\text { Rusya Devlet Başkanı V.V. } \\
\text { Putin }\end{array}$ & 16,0 & 21,3 & 25,3 & 7,3 & 24,7 & 5,3 & $+5,3$ & $+0,08$ \\
\hline
\end{tabular}

Katılımcıların \%5,3'ü yerel idare ve belediye meclisine kesinlikle güveniyor, \% 19,3'ü güveniyor, \% 32'si bazı konularda evet, bazı konularda hayır, \%17,3'ü güvenmiyor yine \%17,3’ü hiç güvenmiyor ve \% 8,7 fikrinin olmadığını beyan etmiştir.

Kat1lımcıların \%4,7'si bölge yasama meclisine tamamen güveniyor, \% 18,7 güveniyor, $\% 32,7$ 'si bazı konularda güveniyor, \% 16'sı güvenmiyor, \% 18'i hiç güvenmiyorken, \% 10'u olumlu veya olumsuz bir yanıt vermemiştir.

Ankete katılanların \%8,7'si valiye tamamen güveniyor, \%14,7'si güveniyor, \% 23,3'ü bazı konularda güveniyor, \%23,3'ü güvenmiyor, \%17,7'si tamamen güvenmiyor ve \%13,3'ü bu soruyu cevaplamamıştır.

Kat1lımcıların \%6,7'si Devlet Duma'sına tamamen güveniyor, \%12’i güveniyor, \%19,3'ü kısmen güveniyor, \%24'ü güvenmiyor, \%32'si hiç güvenmezken, \%6'sı cevap vermekte zorlanmıştır.

Ankete katılanların \%6,7'si Federasyon Konseyine kesinlikle güvenmektedir. \%14'ü güveniyor, \% 21,3 kısmen güveniyor, \%20,7 güvenmiyor, \% 28,7’i kesinlikle güvenmiyorken, \%8,7 olumlu veya olumsuz bir yanıt vermemiştir. 
Katılımcıların \%8'i Rusya Federasyonu hükümetine tamamen güveniyor, \%13,3’ü güveniyor, \% 23,3'ü bazı konularda güveniyor, \%22'i tam olarak güvenmiyor \% 28,7'si hiç güvenmiyorken, $\% 4,7$ 'si cevap vermekte zorlanmıştır.

Başbakan D. A. Medvedev'e katılımcıların \%8,7'si oldukça güven duyarken, \% 9,3'ü güvenmektedir. \%18'i bazı konularda güveniyor, bazı konularda güvenmiyor, \%18,7'si güvenmiyor, $\% 41,3$ hiç güvenmiyor, \%4'ü ise bir fikri olmadığını beyan etmiştir.

Rusya Devlet Başkanı V.V. Putin'e katılımcıların \%16'sı tamamen güven duymaktadır. Ankete katılanlar arasından \% 21,3'ü güvenir, \% 25,3'ü kısmen güvenir/güvenmez, \% 7,3'ü güven duymaz, \% 24,7'si tamamen güvenmez ve \%5,3'ünün ise bir fikri yoktur.

Güven dengesi kurumların olumlu ve olumsuz değerlendirmeleri arasındaki farkı ortaya çıkarmıştır. Cumhurbaşkanı ile ilgili en istikrarlı durum (+\% 5), en kötüsü başbakan (-\%42) ve Devlet Duması (-\% 37,3) olarak ortaya çıkmıştır. Katılımcılar arasında Rusya hükümetine $(-\%$ 29,4) ve Federasyon Konseyi'ne (-\% 28,7) karşı olumsuz bir tutum söz konusudur. Yerel yönetime (-\% 10), bölge parlamentosuna $(-\% 10,6)$ ve valiye $(-\% 16,6)$ tutum orta derecede olumsuz olarak ortaya çıkmıştır.

İktidar kurumlarına olan güven endeksi (olumlu ve olumsuz değerlendirmeler arasındaki farkın, belirli olumlu veya olumsuz değerlendirmeleri ifade eden toplam katılımcı sayısına oranı), şu anda Leningrad Bölgesi ve St. Petersburg'da yaşayan katılımcılar arasında çok düşüktür. Olumlu endeks sadece başkan için güven endeksi (+0.08) vardır. Başbakanın-0.54, Devlet Dumasının -0,5, hükümet ve Federasyon Konseyinin -0.41 , valinin -0.26 , bölge parlamentosunın -0.18 ve yerel yönetimlerin -0.16 ' dir.

Binom değişkenlerinde güven verilerinin iktidar kurumlarına dönüştürülmesinden sonraki çok boyutlu ölçekleme, onlara yönelik tutumdaki farklılıkların derecesini göstermiştir. Bulgular, aynı grupların hükümet ve başbakanların yanı sıra federal düzeyde meclis odalarına güvenme eğiliminde olduklarını gösteriyor. Bölgesel parlamentolara ve yerel yönetime güvenen insan grupları arasında bazı örtüşmeler vardır. Aynı zamanda, cumhurbaşkanı ve bölge yürütme makamlarının başkanları için güven grupları oldukça farklıdır. Analiz, iktidar kurumlarında güven düzeyinin değişkenleri arasındaki istatistiksel olarak anlamlı korelasyon katsayılarını göstermiştir. 
Tablo:35 Yetkililere Güven Değişkenleri Arasındaki Korelasyon Katsayıları Tablosu

\begin{tabular}{|c|c|c|c|c|c|c|c|c|}
\hline Kurumlar & 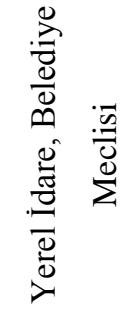 & 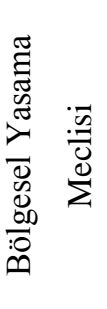 & $\stackrel{7}{>}$ & 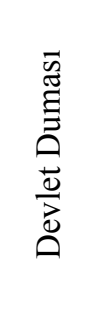 & 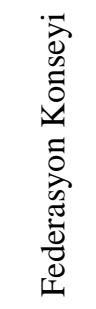 & 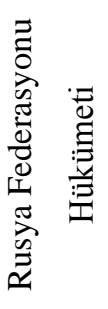 & 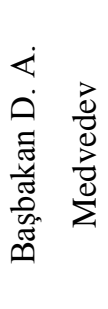 & 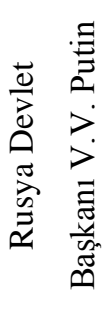 \\
\hline Yerel İdare, Belediye Meclisi & 1 & 0,634 & 0,416 & 0,486 & 0,423 & 0,445 & - & 0,386 \\
\hline Bölgesel Yasama Meclisi & 0,634 & 1 & 0,621 & 0,626 & 0,612 & 0,575 & 0,447 & 0,402 \\
\hline Vali & 0,416 & 0,621 & 1 & 0,628 & 0,705 & 0,677 & 0,583 & 0,462 \\
\hline Devlet Duması & 0,486 & 0,626 & 0,628 & 1 & 0,852 & 0,833 & 0,728 & 0,657 \\
\hline Federasyon Konseyi & 0,423 & 0,612 & 0,705 & 0,852 & 1 & 0,858 & 0,702 & 0,609 \\
\hline Rusya Federasyonu Hükümeti & 0,445 & 0,575 & 0,677 & 0,833 & 0,858 & 1 & 0,759 & 0,711 \\
\hline Başbakan D. A. Medvedev & - & 0,447 & 0,583 & 0,728 & 0,702 & 0,759 & 1 & 0,692 \\
\hline $\begin{array}{c}\text { Rusya Devlet Başkanı V.V. } \\
\text { Putin }\end{array}$ & 0,386 & 0,402 & 0,462 & 0,657 & 0,609 & 0,711 & 0,692 & 1 \\
\hline
\end{tabular}

* İstatistiksel olarak ihmal edilebilir Pearson korelasyon katsayıları atlanmıştır (değerler 0.37 'den az).

Korelasyon analizi, başbakan ve yerel yönetimlere duyulan güven dışında, katılımcıların çeşitli düzeylerde (yüksek istatistiksel olarak anlamlı Pearson korelasyon katsayıları) yetkililere olan güvenlerine ilişkin öz değerlendirmelerinin maksimum düzeyde bağlandığını göstermiştir.

İktidar kurumlarına duyulan güvenin analizi aşağıdakileri göstermiştir:

Ankete katılanların \%46,7'si b hiçbir iktidar kurumuna güvenmiyor. Katılımcıların \%15,3'ü bir, \%11,3'ü iki, \%7,3'ü üç, \% 4'ü dört, \%1,3'ü beş, \%2,7'si altı, \%2'si yedi, \%9,3'ü sekiz iktidar kurumuna güvenmektedir.

Tablo:36 Hükümet Kurumlarına Güvenen Gruplar (\%)

\begin{tabular}{|l|l|}
\hline \multicolumn{1}{|c|}{ Grupların güven seviyesi } & \multicolumn{1}{c|}{$\%$} \\
\hline 1. Yüksek güven & 14,0 \\
\hline 2. Orta güven & 5,3 \\
\hline 3. Az güven & 34,0 \\
\hline 4. Güven yok & 46,7 \\
\hline Toplam & 100,0 \\
\hline
\end{tabular}

Ek veri gruplandırmasından sonra, devlet kurumlarına farklı güven seviyeleri olan katılımcı grupları belirlenmiştir. Güvenmeyenlerin \%46,7'si herhangi bir iktidar kurumuna güvenmediğini belirtmiş, ankete katılanların \%34'ü (1-3 devlet kurumuna güvenerek) yetkililere güven düzeyinin düşük olduğunu; \%5,3 (4-5 devlet kurumuna güvenerek) orta güvene sahip bir grupta iken katılımcıların \%14’ü (6,7 ve 8 devlet kurumuna güvenerek) yüksen güvene sahiptir. 
Aile üyesi başına gelirin 150 - 250 dolar arasında değiştiği kişilerde devlete karşı yüksek veya orta düzeyde güven duyulması diğer gruplara göre daha fazladır. Oldukça düşük gelir grubuna sahip kat1lımcılar (alt ve orta katman arasında) yetkililere güvenmemektedirler.

Yetkili makamlara güvenleri yüksek olan kişiler Vkontakte sitesini kullanma eğiliminde değildir; elektronik kamu hizmetleri sistemini kamuya uygun olarak değerlendirmek konusunda diğer gruplara göre daha meyillidirler, ancak elektronik belge yönetiminin genişlemesini desteklememekte ve elektronik belge yönetimini kullanırken vatandaşların kişisel bilgi güvenliği ile ilgili soruları cevaplamayı zor bulmaktadırlar. Aynı zamanda, bu insan kategorisi, elektronik belge dolaşımını kullanma sürecinde devletin mahremiyet hakkının ihlali, devletin tam kontrol sağlama isteği konusunda endişeye daha az meyillidir. $\mathrm{Bu}$ insanlar, nüfusun e-hükümet, platformlar ve araçları konusunda devlete duydukları bilinç düzeyini yeterince göz önünde bulundurma eğilimindedir. Hükümete karşı ortalama güven sahipleri YouTube'daki bilgilerin kullanımına güvenme eğilimindedir. Hükümete güvenleri düşük olan insanlar kamu hizmeti bilişim kapısı kullanımını diğer gruplara göre daha zor bulmaktadırlar. Kamu otoritelerine tamamen güven eksikliği olan katılımcılar, diğer gruplardan daha fazla elektronik platformlar kullanırken, buralarda kişisel verilerin gizliliğinin garanti altına alındığına ikna olmuş durumdadırlar.

Araştırma sırasında, iktidarın güven ve e-hükümet kalkınma politikasına yönelik tutumlar arasında istatistiksel olarak onaylanmış bir bağımlılı̆̆ tespit edilmemiştir.

\section{Sonuç}

St. Petersburg ve Leningrad Bölgesi'nde yapılan bu sosyal araştırma sırasında nüfusun ehükümet ve teknoloji kullanım kültürünün varlığı oldukça yüksek bir düzeyde olduğu ortaya çıkmıştır.

Rusya Federasyonu'nda dijital hükümet hizmetleri bilişim kapısı aktif sayılabilecek düzeyde kullanılmaktadır. Kalan diğer dört bilişim kapısı ise, oranı önemsiz sayılabilecek katılımcı tarafından tercih edilmektedir. Diğer e-hükümet araçları ve kurumlarından sadece MFTS'nin hatırı sayılır kullanıcısı mevcuttur. E-imza kullanım oranları ise henüz beklenenin çok daha altında olduğu gözlemlenmiştir. Ayrıca hükümet hizmetleri web sitesine erişmenin bir yolu olarak "infomat" da çok az kullanılmaktadır. Katılımcılar tüm bu elektronik platformlara giriş yöntemi olarak akıllı telefonları tercih etmektedir. Masaüstü ve dizüstü bilgisayarların kullanım kolaylığı açısından tercih edilişleri ise aynı orandadir.

Vatandaşların mevcut elektronik hükümet platformlarını kullanım rahatlığına ilişkin algılarının değerlendirilmesi, kullanılan platform ve araçlarının sayısı arasında işlevsel bir bağımlılık tespit edilmiştir. Buna göre: bilişim kapısı katılımcılar tarafından ne kadar çok kullanılırsa o kadar tehlikesiz olarak değerlendirilmekte ya da tam tersi ne kadar az kullanılırsa o kadar tehlikeli olduğu düşünülmektedir. 
Vatandaşların kişisel bilgi güvenliği konusundaki öznel fikirlerinin olumlu yönde seviyesini artırmak ve verilerinin kamu hizmeti web sitelerine aktarılmasının gizliliğini sağlamak, e-hükümet hizmet araçlarının kullanımının sürdürülebilirliği için oldukça önemli olduğu gözlemlenmiştir. Ehükümete yönelik farklı tutumların ve değerlendirmelerin olması, temelde araştırmaya katılan sosyal grupların yaş, eğitim ve statü özellikleri ile ilgilidir.

Katılımcılar internet bilişim kapılarını kullanırken, kişisel bilgi güvenliğinin sağlanıp sağlanmadığ 1 hususunda oldukça olumsuz değerlendirmelerde bulunmuşlardır. Elektronik belge dolaşımında güven düzeyi düşük çıkmıştır. Olası riskler olarak örneğin; bilgisayar korsanlarının siteleri ele geçirme ihtimali, kişisel verilerin üçüncü kişilere sızdırılabileceği düşüncesi, verileri devletin elektronik servis sitelerinde depolanan kişilerin doğrudan dolandırıcılık amaçlı kullanılabileceği, teknik hatalar ve belge gönderirken karşılaşılması muhtemel olumsuzlar, vatandaşların mahremiyetinin ihlali gibi konular katılımcıların güven düzeyinin düşük çıkma sebebine cevaptır. Böylesi bir durumda eğer insanların olası bu risklerle karşılaşmayacaklarına dair herhangi bir teminatı olduğunda ise bizlerde elektronik belge dolaşımına güven potansiyelinin yüksek çıkacağı fikri oluşmuştur.

Aynı zamanda bu çalışma insanların kitle bilincindeki iktidar kurumlarını değerlendirmenin doğrusal bir yolunu da ortaya çıkarmıştır. Bu istihbarat anketinde, e-hükümetin işleyişine dair çeşitli göstergelerin değerlendirilmesi ile çeşitli iktidar kurumları ve siyasi seçkinlerin temsilcileri ile istatistiksel olarak doğrulanmış önemli bir güven bağı bulunamamıştır.

Vatandaşların dijital ekonomiye, e-hükümete ve diğer çeşitli tezahürlerine karşı oldukça olumlu bir tutum sergilemeleriyle, bu görüngüleri gerçek anlamda anlama düzeyleri ve bunlara karşı olumlu tutumları arasındaki bağ çok düşüktür.

Günümüz Rusya Federasyonu'nda, nüfusun çoğunluğu için dijital hükümetin nasıl işlediği konusunda farkındalık düzeyi, hükümet hizmetleri bilişim kapısı, MFTS ve diğer çeşitli işlevleri gerçekleştiren sistemlerde daha öncesinde işlem yapan kişilerle sınırlıdır. Bu durum, kullanıcıların var olan hizmetlerden yararlanabileceği fakat ileride yeni hizmetler açısından bir talepte bulunmayacakları düşüncesini de akıllara getirmektedir. E-hükümet hizmetleri için düşük bilgi seviyesi ve talep (dijital devletin e-formları konusunda) kısmen devletin etkisiz bir bilgi politikasına sahip olduğu kanısına varmamıza yol açmıştır.

Dijital hükümetin çeşitli elektronik platformlarının kullanımında sürdürülebilir uygulamaların geliştirilmesindeki en büyük farklılıklar, yaş, bilgi okuryazarlık düzeyi ve mesleki faaliyetin doğası bakımından çeşitlilik gösteren sosyal gruplar arasında gözlenmiştir. 


\section{Kaynakça}

Bancroft A. ve Reid P. S. (2017) "Challenging the Techno-Politics of Anonymity: the Case of Crypto- market Users", Information, Communication \& Society, Vol. 20. No.4. ss. 497-512. [URL: https://doi.org/10.1080/1369118X.2016.1187643 Erişim Tarihi: 17.12.2017].

Bennett L., Segerberg A. (2013) The Logic of Connective Action, Digital Media and the Personalization of Contentious Politics, Cambridge: Cambridge University Press.

Berman S. J., Korsten P. J. ve Marshall A. A (2016) "Four-Step Blueprint for Digital Reinvention", Strategy \& Leadership, No. 44 (4). ss. 22-34.

Blanc J. (2017) "Making Sense of the Plurality of Money: A Polanyian Attempt", SASE 29th Annual Meeting (Society for the Advancement of Socio-Economics), Lyon, France, $24 \mathrm{~s}$.

Borzel T. (1998) "Rediscovering Policy Networks as a Form of Modern Governance", Journal of European Public Policy, Vol. 5. No. 2. ss. 222-299.

Brabham D. (2008) "Crowdsourcing as a Model for Problem Solving: An Introduction and Cases", Convergence: The International Journal of Research into New Media Technological Studies, Vol. 14. No.1. ss. 75-90.

Brandes U., Kenis P., Raab J., Schneider V. ve Wagner D. (1999) "Explorations in to the Visualization of Policy Networks", Journal of Theoretical Politics, Vol. 11. ss. 75-106.

Breuer A., Landman T. ve Farquhar D. (2015) "Social Media and Protest Mobilization: Evidence from the Tunisian Revolution", Democratization. Vol. 22. No. 4.

Burt R. S. , Brokerage and Closure (2005) An Introduction to Social Capital, Oxford: Oxford University Press.

Clemons E., Dewan R., Kauffman R. ve Weber Th. (2017) "Understanding the Information-Based Transformation of Strategy and Society", Journal of Mangement Information Systems, Vol. 32. No. 2. ss. 315-420.

Compston H. (2009) Policy Networks and Policy Change. Putting Policy Network Theory to the Test, N.Y.: Palgrave Macmillan.

Daugbjer C. (1998) Policy Networks under Pressure: Pollution Control, Policy Reform and Power of Farmers, Aldershot: Ashgate Publishing.

Elliot A., Lemert C. (2009) The New Individualism: The Emotional Costs of Globalization, N.Y.: Routledge.

Enikolopov R., Petrova M. ve Zhuravskaya E. (2011) "Media and Political Persuasion: Evidence from Russia", The American Economic Review, No. 101.

Hinton G. E, Osindero S. ve Teh Y.W. (2006) “A Fast Learning Algorithm For Deep Belief Nets", Neural Computation Neural Computation, Vol. 18. No. 7.

Hirst P. (2000) "Democracy and Governance, Debating Governance", J. Pierre (Ed.); Oxford: Oxford University Press.

Knoke D. (1990) Political Networks. The Structural Perspective, N.Y.: Cambridge University Press.

Knoke D., Kuklinski J. H. (1982) Network Analysis, Beverley Hills, CA: Sage Publications.

Kooiman J. (2003) Governing as Governance, L.: Sage Publications.

Kooiman J. (1993) "Social-Political Governance: Introduction, Modern Governance", New Government - Society Interactions, J. Kooiman. L. (Ed.); Sage Publications, ss. 1-6.

López-Iturriaga F. J. ve Sanz I. P. (2017) "Predicting Public Corruption with Neural Networks: An Analysis of Spanish Provinces", Social Indicators Research.

Monge P. R. ve Contractor N. S. (2003) Theories of Communication Networks. N.Y.: Oxford University Press.

Moore D. ve Rid T. (2016) Cryptopolitik and the Darknet, Survival, Global Politics and Strategy.

Mutzel S. (2009) "Networks as Culturally Constituted Processes: A Comparison of Relational Sociology and Actor-Network Theory", Current Sociology, Vol. 57. No. 3. ss. 621-734.

Noveck B. (2009) Wiki Government: How Technology Can Make Government Better, Democracy Stronger and Citizens More Powerful, Washington: Brookings Institution Press. 
O'Reily T. (2010) “Government as Platform”, D. Lathrop (Ed.). Open Government: Collaboration, Transparency, and Participation in Practice, Sebastopol, Calif.: O’Reily Media.

OECD Comparative Study (2016) "Digital Government Strategies for Transforming Public Services in the Welfare Areas", [URL: http://www.oecd.org/gov/digital-government/Digital-Government-Strategies-WelfareService.pdf Erişim Tarihi: 07.10.2017]

Rihoux, B., \& Ragin, C. C. (2009) "Configurational comparative methods. Qualitative Comparative Analysis (QCA) and related techniques (Applied Social Research Methods)” Thousand Oaks and London: Sage.

Putnam R. D. ve Feldstein L. M. (2003) Better Together: Restoring the American Community, N.Y.: Simon \& Schuster.

Reuter O. J. ve Szakonyi D. (2014) “Online Social Media and Political Awareness in Authoritarian Regimes”, British Journal of Political Science, No. 45.

Salovaara I. (2012) "Beth Simone Noveck: Wiki Government: How Technologies can make Government Better, Democracy Stronger and Citizens More Powerful", Journal of Media and Communication, Issue 52. ss. 153184.

Schwab K. (2016) "The Forth Industrial Revolution: What it Means and how to respond", Foreign Affairs, December. ss. 1-7.

Schwarz J. A. (2017) "Platform Logic: An Interdisciplinary Approach to the Platform-Based Economy", Policy and Internet, No. 9. s. 4.

Smyth R. ve Oates S. (2015) "Mind the Gaps: Media Use and Mass Action in Russia”, Europe-Asia Studies, Vol. 67 (2).

Tarrow S. (1994) Power in Movement: Social Movements, Collective Action and Politics, Cambridge: Cambridge University Press.

Tilly C. (1978) From Mobilization to Revolution, Reading MA: Addison-Wesley.

Van Dijck J. (2017) "The Platform Society", Public Values in a Connective World, Keynote, April 27. JMK, Stockholm University.

Waarden F. (1992) "Dimensions and Types of Policy Networks", European Journal of Political Research, Vol. 21. No. 1-2. ss. 16-44. 